\title{
Elmar Altvater:* Om nogle problemer ved statsinterventionismen
}

I nedenstående tekst forsøger Altvater at udvikle begrebet om staten under kapitalismen gennem en dobbelt analyse; dels gennem en udvikling af det Marx'ske begreb om staten, især fra »Grundrisse« og »Das Kapital«, dels gennem konkrete - historiske analyser af udviklingen i eksisterende statsformer (specielt den nuværende vesttyske stat).

Artiklen må ikke betragtes som den endelige og uigendrivelige fremstilling af teorien om den kapitalistiske stat tværtimod må den ses som et forsøg på at bidrage til videreudviklingen af den Marx'ske statsteori.

Da den teoretiske del af Altvater's analyse i høj grad bygger på kategorien »kapital i almenhed«, vil det lette forståelsen af denne tekst, hvis den også her i nummeret bragte artikel af af Roman Rodolsky om udviklingen af samme kategori hos Marx er gennemarbejdet i forvejen.

*. Oversat efter: »Zu einigen Probleme des Staatsinterventionismus«; i: Probleme des Klassenkampfs, Heft 3, 1972, s. 1-53. Om oversættelsen er der at sige, at vi har forsøgt at holde den tæt til originalens formuleringer, hvilket ikke har gjort teksten let tilgængelig i sin danske form; et forhold som vi dog håber kan opvejes af den større grad af præcision og skarphed i de teoretiske fremstillinger, som originalteksten rummer. 


\section{Indledning}

Jeg skal her forsøge at udlede mulighederne og grænserne for statsinterventionisme $^{1}$ i det borgerligt-kapitalistiske samfund. Men for at kunne bestemme disse muligheder og grænser må statens funktioner i det kapitalistiske samfund udvikles i en mere almen betydning, end de antydes i begrebet statsinterventionisme. Enhver begrænsning af analysen til blot at omfatte funktionerne af den økonomisk forstående statsinterventionisme må på forhånd blive blind over for det kapitalistiske samfunds almene funktionsbetingelser og dets statsfunktionsbetingelser, og derfor også overfor erkendelsen af mulighederne og grænserne, da disse jo netop gives ud fra samfundets specifikke form. Man kan på den anden side ikke blive stående ved en almen bestemmelse af den borgerlige stats »væsentlige karaktertræk«, hvis man skal behandle nogle spørgsmål i forbindelse med statsinterventionismen. Thi de samfundsmæssige krisers fremtrædelsesformer - og dermed også statens interventionistiske svar - er underlagt historiske forandringer, der stiller enhver analyse overfor alvorlige problemer, som her indledningsvis skal berøres kort.

Hvis man ikke stræber efter at udlede »bevægelsen i abstrakt tilstand«, som »den rene fornufts bevægelse « rent logisk, ${ }^{2}$ så gælder det om at opdage det bestående samfunds indre struktur i dette samfunds historiske betingelser og udvikling. Under forløbet af forskningsprocessen må man derfor, som Marx skriver, »tilegne sig stoffet i detaljer, analysere dets forskellige udviklingsformer og opspore disses indre forbindelse. Først når dette arbejde er fuldført, kan den virkelige bevægelse fremstilles overensstemmende hermed. Lykkes dette, og genspejles stoffets liv nu i ideens form, så kan det se ud som om man har at gøre med en konstruktion a priori «. ${ }^{3}$

Denne forklaring på den marxske forskningsproces lader sig kun tolke i den retning, at den højtudviklede kapitalismes mangfoldige og komplicerede fremtrædelsesformer selv må være undersøgelsens genstand og enhver programmatisk begrænsning til den marxske fremstilling af kapitalbegrebet giver et resultat, der selv kun kan forstås rigtigt som resultat af en erkendelsesproces - som resultat

1. Allerede begrebet statsinterventionisme er problematisk. Det implicerede jo i de gængse forestillinger et ydre forhold mellem samfund, dets økonomiske struktur og staten. Det giver indtryk af, at det i forholdet mellem økonomi og stat drejer sig om et forhold mellem det regulerede og det styrende subjekt. I denne artikel forsøger jeg dog netop at kritisere denne forestilling. Men da begreberne "statslig regulering«, "planlægning under kapitalismen«, »krisemanagement « o.lign. ikke frembyder virkelige alternativer, fastholdes i det følgende det problematiske begreb statsinterventionisme.

2. "Ligesom vi har forvandlet enhver ting til en logisk kategori gennem abstraktionen, behøver man kun at abstrahere fra enhver udskillelig egenskab ved de forskellige bevægelser for at nå frem til bevægelsen i abstrakt tilstand, til den rent formelle bevægelse, til bevægelsens rent logiske formel. Har man først fundet alle tings væsen i den logiske kategori, så bilder man sig ind at finde den absolutte metode i bevægelsens logiske formel: den absolutte metode, der ikke blot forklarer alle ting, men som også omfatter tingenes bevægelse. [. . .] Men hvad er så denne absolutte metode? Bevægelsens abstraktion? Bevægelsen i abstrakt tilstand. Hvad er bevægelsen i abstrakt tilstand? Bevægelsens rent logiske formel eller den rene fornufts bevægelse ... « K. Marx: Das Elend der Philosophie, MEW 4, s. 128.

3. K. Marx: Kapitalen, Efterskrift til 2. oplag, Kbh. 1970. Bog 1:1, s. 105. 
af en omfattende forskningsproces. Denne erkendelsesproces - forstået som en gennemført arbejdsdelt, d.v.s. kollektiv, organiseret teoretisk arbejdsproces - må som forskningsarbejde også omfatte den højtudviklede kapitalismes særtræk, og den kan ikke afkortes ved, at man overtager »den færdige almene teori om kapitalen « - d.v.s. den marxske fremstilling af kapitalbegrebet - og tilegner sig den i alle dens forgreninger. Dette kan og skal ikke betyde, at det er overflødigt at beskæftige sig intensivt med den marxske teori, at tilegne sig den nøjagtigt og rekonstruere den. Det er tværtimod først studiet af »Kapitalen« og den deraf følgende logiske indtrængen i det bestående samfunds indre struktur, der gør det muligt at udvikle problemstillinger, som formår at vejlede den forskningsproces, der udgår fra de historiske fremtrædelsesformer. (Problemstillinger findes efter min mening på ethvert trin i tilegnelsen af KAPITALEN og ikke først på det mystiske tidspunkt, hvor teori slår om i metode). Denne forskningsproces gennemføres altid mere eller mindre godt af subjekter, der befinder sig i en bestemt historisk og politisk sammenhæng. Den kan kun fastlægges foreløbigt så længe problemstillinger - eller endda knap nok dette - udledes alene af »kapitalbegrebet i almenhed «, uden at de herskende teoretiske og objektive historiske betingelser kritiseres - betingelser der selv bestemmer den herskende bevidsthed, også selvom denne kritik blot er foreløbig og ikke systematisk i alle forhold. »Teoretikeren« har det her ikke bedre end den "praktiske politiker«: for ikke bestandigt at humpe afsted efter de objektive og subjektive betingelser er det nødvendigt at vende sig mod problemer og forsøge at løse dem, selv om forskningens systematiske gang og udarbejdelsen af teorier egentlig endnu ikke tillader det. Marx tog selv permanent stilling til aktuelle politiske spørgsmål i artikler, erklæringer, taler og adresser uden hver gang at vende tilbage til »kapitalbegrebet i almenhed « i detaljer - ja, endog uden at have udarbejdet dets systematik. Han afholdt sig ikke fra at tolke den empiriske overflade og drage slutninger herfra; de problemer, som de historiske forhold rejste, foranledigede eller direkte tvang ham til at gøre det, og vi er i vores historiske epoke på samme måde tvunget til det. For så vidt er tilegnelsen af den marxske teori ubetinget nødvendig, ikke som et instrument, der må læres for man beskæftiger sig med problemerne i den virkelige bevægelse og teori, og heller ikke som et dogme, der stadig må udlægges »ex cathedra«, men derimod som en begrebslig abstraktion af kapitalforholdets virkelige bevægelse, som med kapitalismens udvikling fremtvinger nye spørgsmål; spørgsmål, som ganske vist ikke vedrører dette samfunds væsen - formen for dets modsigelser - men dog kapitalforholdets fremtrædelsesformer. Og denne »realanalyse« omfatter både væsensanalysen og analysen af fremtrædelsesformerne (både i deres systematiske begrebslige udledning og i deres konkrete historiske forløb). Betoningen af denne »to-sporede« fremgangsmåde- tilegnelsen af Marx' fremstilling af kapitalbegrebets logiske struktur og analyse af kapitalismens konkrete historiske fremtrædelsesformer - må på ingen måde opfattes som et metodisk postulat. Der findes iøvrigt ingen kongevej fra 
det almene kapitalbegreb til kapitalforholdets overflade og et konkret samfunds historiske udviklingsforløb. Tosporetheden er langt snarere politisk begrundet ud fra erkendelsen af, at man ikke kan vente med analysen af konkrete problemer til, man har nået det punkt, hvor teori endelig slår om i metode. (Dette punkt kan slet ikke komme, da enhver undersøgelse, der kun henholder sig til kategoriernes logik og som ikke er »koblet tilbage« til det forskende subjekts politiske betingelser, udsætter sig for de kategoriale udledningers uendelighed).

Mens den borgerlige stats særlige form i de »væsentlige karaktertræk « er fælles for alle kapitalistiske samfund, ${ }^{4}$ opstår problemet med den moderne statsinterventionisme først i den fase af kapitalforholdets udvikling, hvor der er opstået historiske betingelser såsom dannelsen af et kapitalistisk verdensmarked, en skærpet klassekamp i national og international målestok, et udviklet statsapparat sammen med en institutionel indkapsling af konflikten mellem lønarbejde og kapital osv. På grundlag af statens væsentlige karaktertræk i kapitalismen gennemføres forandringer i statsfunktionerne, som analysen af de væsentlige karaktertræk langt fra har greb om. Det kommer derfor netop an på at gå disse kort antydede historiske betingelser nøje igennem for at lade hele problemet komme til sin ret, ligesom det også kommer an på at kritisere de dermed opståede teorier som systematiseringer af denne tilstand, hvilket jeg også skal forsøge i denne artikel med enkelte eksempler. Den almene teori kan ikke holdes frem mod den »snavsede« historie som et »tryllespejl«, hvori alle spor af empiriens smudsigheder er forsvundet. Det fordrejede skær, som kapitalens væsen fremstår i, fremstår også som virkelige kategorier, historisk udviklende former, som dette samfund reproducerer sig materielt i. Statsinterventionismen - og teorierne om den - må derfor ikke blot kritiseres for at være falske forestillinger om statsfunktionerne i kapitalismen, men må i høj grad forstås som statens virkelige aktioner overfor samfundet under altid skiftende historiske betingelser. ${ }^{5}$ Først på dette grundlag bør teorierne om statsinterventionismen kritiseres.

Under hensyntagen til de antydede vanskeligheder vil det i denne artikel kun dreje sig om at undersøge visse af statsinterventionismens almene, nutidige, relevante fremtrædelsesformer, som alle behøver en yderligere konkretisering

4. »Imidlertid har de forskellige kulturlandes forskellige stater, trods den brogede forskel imellem dem hvad formen angår, alle det til fælles, at de står på det moderne borgerlige samfunds grund, kun at dette samfund er mere eller mindre udviklet i kapitalistisk henseende. De har derfor også visse væsentlige karaktertræk til fælles. I denne forstand kan man tale om den 'nuværende stat' i modsætning til fremtiden, da dens nuværende rod, det borgerlige samfund, vil være døet bort.« K. Marx: Kritik af Gotha Programmet, MEUS, Bd. II, Kbh. 1952, s. 25. Få linier tidligere skriver Marx: »Derimod skifter den 'nuværende stat' med landegrænsen. Den er anderledes i det preussisk-tyske rige end i Schweiz, anderledes i England end i De Forenede Stater. 'Den nuværende stat' er altså en fiktion.« (ibid.)

5. Ud fra dette udsagn må man ikke slutte forhastet, at den teoretiske indsigt i betingelseskomplekset stat, samfund og økonomi er i stand til at effektivisere statens virkelige aktioner over for samfundet, altså statsinterventionisme i den herskende klasses mening og interesse. Netop derved ville man miste den teoretiske indsigt, at også den herskende klasse er fanget i det kapitalistiske samfunds modsigelser, som den ikke kan styre og kontrollere. Da denne forkerte opfattelse af staten - ligesom samfundsvidenskabernes betydning for den borgerlige klasses herredømme er vidt udbredt, og da den fører til store politiske fejlslutninger, vil jeg vende tilbage til dette i artiklens sidste afsnit. 
og uddybning. I det følgende vil jeg først forsøge at udarbejde den borgerlige stats væsentlige karaktertræk i det omfang, det er nødvendigt for problemstillingen, og i tilknytning hertil i særdeleshed at undersøge skabelsen af de almene materielle produktionsbetingelser gennem den borgerlige stat for dernæst at vende mig mod forsøgene med statslig »krisemanagement«. Her vil jeg især interessere mig for problemet 'stagflation'. I den afsluttende del gennemføres en eksemplarisk undersøgelse af spørgsmålet om og hvorvidt den borgerlige videnskabs fremskridt kan effektivisere de statslige aktioner i det kapitalistiske samfund. Valget af netop disse problemfelter skyldes mindre en udviklet systematik til fremstillingen af statsproblemet og mere deres politiske vigtighed. Artiklen forstås selv som et bidrag til udviklingen af en marxistisk statsteori.

\section{Statens 'specificering' i det borgerlige samfund}

Under kapitalismen er staten et organ for kapitalens herredømme over lønarbejderklassen. Dette udsagn er ikke alene en kendsgerning, som er erfaret igen og igen i de forskellige kapitalistiske landes hidtidige historie, men også en kendsgerning, som kan udledes. For at kunne foretage denne udledning må man undersøge det klasseforhold, som udtrykker sig politisk i det borgerlige samfund, idet man går ud fra den kapitalistiske reproduktionsproces' betingelser og bestemmer statens funktioner heri. Denne udledning bliver dog ikke gennemført her, da vi begrænser os til en side af de statslige aktioner, nemlig dens aktioner overfor de mange enkeltkapitaler. For vores problem bliver det afgørende spørgsmål, hvorledes den reelle sammenføjning af det bestående samfund følger af de mange enkeltkapitaler og hvilken betydning, der herved tilkommer staten.

Ved Marx’ analyse af området: »kapitalen i almenhed « ${ }^{6}$ forudsættes kapitalens reelle eksistens som samfundsmæssig totalkapital. Totalkapitalen er en sammenføjning, forstået som den reelle gennemsnitseksistens af mange enkeltkapitaler, hvis subjektive handlen frembringer gennemsnitsbetingelserne som totalkapitalens betingelser - $\mathrm{i}$ overensstemmelse med de eksisterende betingelser - som et resultat »bag deres ryg «. Den kapitalistiske produktionsmådes 'udviklingslove' refererer således altid til totalkapitalen, aldrig til de mange enkeltkapitaler, som dog i deres handlinger er bevidstløse skabere af de kapitalistiske lovmæssigheder. Det er ikke totalkapitalen, som handler, men de mange enkeltkapitaler; men i deres handlinger frembringer enkeltkapitalerne totalkapitalens eksistensbetingelser: gennemsnitlige udbytningsregler, samme merværdirate og gennemsnitsprofitrate. Gennemsnitsbetingelserne og deres lovmæssige bevægelser bliver

6. Vi går ikke nærmere ind på betydningen af denne kategori, og henviser til den indtil i dag bedste behandling hos Roman Rosdolsky: Zur Entstehungsgeschichte des Marxschen 'Kapitals', Frankfurt/Wien 1968, s. 24-124, især s. 61 ff. Se KURASJE, nr. 7, s. 66-76. 
analyseret på det begrebslige felt: »Kapitalen i almindelighed «, dvs. at enkeltkapitalernes handlen interesserer ikke som sådan, men kun i deres resultater. ${ }^{7}$ Det er ligeledes også på det begrebslige område: Kapitalen i almenhed, hvori den form udvikles, som udfra og imod de mange enkeltkapitaler sætter sig igennem som den kapitalistiske produktionsmådes almene love. Denne form er konkurrencen, som den kapitalistiske produktions immanente tvangslove gør sig gældende i. Men konkurrencen er ikke kun en form, som et hvilket som helst indhold kan sætte sig igennem $\mathrm{i}$, men derimod netop formen for gennemslaget af kapitalens immanente love. Den er altså ikke blot et instrument, ligegyldig overfor indholdet, men et reelt og begrebsligt nødvendigt moment i frembringelsen af kapitalen som totalkapital. Den reelle totalkapitals gennemsnitbetingelser og bevægelser er den reelle basis for den begrebslige abstraktion »kapitalen i almenhed « ${ }^{8}$

I konkurrencen kan kapitalen dog kun frembringes som totalkapital for såvidt som enkeltkapitalerne virkeligt står i relation til hinanden. Og dette kan de kun for så vidt som de handler kapitalistisk, dvs. som merværdiproducerende kapitaler. Det er ikke alle samfundsmæssige funktioner, som lader sig udføre kapitalistisk i denne betydning, hvad enten det er, fordi produktionen af visse (materielle) produktionsbetingelser ikke afkaster profit, eller fordi mange ordninger besidder en for stor grad af almenhed til at enkeltkapitalerne med deres særinteresser kan realisere dem under de foreliggende konkrete betingelser. Det følger altså nødvendigvis af produktionens kapitalistiske form, at enkeltkapitalerne både konstituerer sig som totalkapital i konkurrencen og at denne konstituering til kapitalistisk samfund ikke alene kan ligge i konkurrencens form. Hindringen ligger i kapitalen selv, da de samfundsmæssige relationers specifikke form - varebytte og kapitalproduktion - ikke kan lade de bestemte forhold opstå, hvis frembringelse ikke er profitabel eller sker i en udstrækning og under betingelser, som truer hele samfundets eksistens (destruktion af et samfunds eller »omgivelsernes« naturlige ressourcer er et aktuelt eksempel). Kapitalen kan således ikke af sig selv producere den samfundsmæssige eksistens, som er anlagt i den, gennem de mange enkeltkapitalers handlinger; den behøver en særlig indretning på sit eget grundlag, som ikke er underlagt dens grænser som kapital, hvis handlinger altså ikke

7. Dette udtrykker Marx tydeligt i kapitel 10 i første bind af KAPITALEN: »Vi vil ikke for øjeblikket undersøge, hvorledes den kapitalistiske produktions immanente love fremtræder i kapitalernes ydre bevægelse, hvorledes de gør sig gældende som konkurrencens tvangslove og derfor opstår i den individuelle kapitalists bevidsthed som herskende motiver ... Kapitalen, Kbh. 1970, bog 1:2 s. 475. Det drejer sig om for Marx at begrunde den relative merværdiproduktions immanente nødvendighed, og ikke om at begrunde den mekanisme, der får enkeltkapitalerne til at gennemføre denne nødvendighed gennem deres handlen. Tilfældet er anderledes og mere kompliceret ved behandlingen af gennemsnitsprofitratens dannelse i 2. afsnit af 3. bog. Dette kan vi dog ikke tage op her. Ved behandlingen af konkurrencen må to aspekter i konkurrencebegrebet adskilles: »kapitalen som sig selv og sin egen overflade, som processerende enhed af væsen og fremtrædelsesform, der kommer til udtryk i selve den begrebslige fremstilling; og så kapitalen i den historiske realitet. Helmut Reichelt: Zur logischen Struktur des Kapitalbegriffs bei Marx, Frankfurt/Wien 1970, s. 85.

8. Herom skriver Marx i "Grundrisse«, Berlin 1953, s. 353. (Afsnittet er gengivet i Rosdolsky's artikel, KURASJE, nr. 7, s. 71 - jvf. fodnote 29 der). 
er bestemt af merværdiproduktionens nødvendighed - en særlig indretning som $i$ denne forstand er »ved siden af uden og for det borgerlige samfund «, ${ }^{9}$ og som på kapitalens uantastede grundlag kan opfylde de immanente nødvendigheder, som kapitalen forsømmer. Som følge heraf udvikler det borgerlige samfund en specifik form i staten, en form, der udtrykker kapitalens gennemsnitsinteresser. ${ }^{10}$ Staten kan altså ikke forstås hverken som et rent politisk instrument, eller som en fra kapitalen adskilt institution, men kun som den særlige form, som kapitalens samfundsmæssige eksistens sætter sig igennem i ved siden af og uden for konkurrencen, som et væsentligt moment i kapitalens samfundsmassige reproduktionsproces. ${ }^{11}$

Selv om staten altså udtrykker kapitalens gennemsnitsinteresser, sker det dog ikke på en modsigelsesfri måde. Thi begrebet for kapitalens gennemsnitseksistens ophæver ikke de mange enkeltkapitalers aktioner og interesser, der som sådan står modsætningsvis overfor hinanden. Disse modsætninger ophæver ikke konkurrencen, de skyldes heller ikke konkurrencen eller »markedets anarki«, hvor de fremtræder, og staten kan heller ikke fjerne dem. I denne forstand er staten altså aldrig virkelig, materiel totalkapitalist (= kollektivkapitalist, o.a.), men altså kun ideel eller fiktiv totalkapitalist. ${ }^{12}$ Dette er indholdet af kategorien "statens specificering", det borgerlige samfunds "fordobling" $\mathrm{i}$ samfund og stat. Allerede på dette sted kan man drage en vigtig slutning heraf: staten substituerer ikke konkurrencen, men den træder ved siden af den, og med hensyn til vardiloven, som er begrebsligt sammenfattende for de immanente love for konkurrencens gennemslag, betyder det ikke en erstatning af den og slet ikke dens ophævelse, men dens modsvarende modifikation. Således

9. Marx/Engels: Die deutsche Ideologie, MEW 3, s. 62. Marx og Engels bestemte den borgerlige stats særlige eksistens ud fra "privatejendommens emancipation fra fællesskabet«; dvs. ud fra det borgerlige samfund og dets stats historiske udvikling, ud fra emancipationen fra førkapitalistiske former for samfundsmæssig organisation.

10. Staten »er dog endnu intet andet end den form for organisation, hvori borgerskabet nødvendigvis giver sig gensidige garantier for både ejendom og interesser, såvel indadtil . . hvori den herskende klasses individer gør deres fælles interesse gældende, og som sammenfatter hele det borgerlige samfund i en epoke ...«, MEW, Bd. 3, s. 62.

11. Hermed er bestemte opfattelser kritiseret, dels de, der optræder i bestemte varianter af teorierne om den statsmonopolistiske kapitalisme, hvor staten bliver de mægtigste monopolers instrument, og dels de, der fremføres i de fleste borgerlige teorier, hvor staten er reguleringens autonome subjekt. Det bør nævnes, at teorierne om den statsmonopolistiske kapitalisme er meget forskellige i netop dette spørgsmål. På den ene side ses staten som en ensartet mekanisme, der sammenfatter monopolernes og statens magt - altså en påstand om en sammensmeltning af monopolmagt og stat - på den anden side bliver staten opfattet simpelt som »monopolbourgeoisiets instrument«. Man kan ikke bestride, at stat og kapital er sammenflettet til en ensartet mekanisme, men det kommer dog netop an på at undersøge denne »mekanismes« funktionsbetingelser nøje. Og dtete problem har statsmonopolkapitalismeteoretikerne endnu ikke løst.

12. Engels: Anti-Dühring, MEW, 20, s. 260: „Og den moderne stat er igen kun den organisation, som det borgerlige samfund giver sig for at opretholde de almene ydre betingelser for den kapitalistiske produktionsmåde mod overgreb, såvel fra arbejderen som fra enkeltkapitalisterne. Uanset dens form er den moderne stat i det væsentlige en kapitalistisk maskine, kapitalisternes stat, den ideelle totalkapitalist . . « Vi kan dig ikke være enige med Engels i formuleringen: "Jo flere produktivkræfter (staten, E.A.) overtager i sin eje, desto mere bliver den virkelig totalkapitalist « - ganske vist bliver staten til virkelig kapitalist gennem overtagelse af kapitalistiske produktionsprocesser, men ikke til totalkapitalist. Staten er som kapitalistisk producent underlagt enkeltkapitalernes indbyrdes modsætninger, ligesom andre store enkeltkapitalister også er det. Som det vil fremgår, er det netop denne konstituering som virkelig kapitalist problematisk for kapitalen. 
er det først staten, der gør konstitueringen af det i enkeltinteresser opdelte samfund historisk muligt netop på grund af det faktum, at den sikrer dens eksistensgrundlag (såsom opretholdelsen af lønarbejderklassen som kapitalens udbytningsobjekt, skabelsen af de almene produktionsbetingelser, retsforhold) - det eksistensgrundlag, som kapitalen enten tenderer til at destruere igen som følge af den tvang, som skabes gennem konkurrencen, til maksimal værdiøgning af kapitalen ${ }^{13}$ eller som den slet ikke formår at frembringe, da betingelserne for denne frembringelse implicerer ikke-kapitalistisk produktion (hvilket gælder for en stor del af de almene produktionsbetingelser). Staten varetager altså funktioner til opretholdelse af det kapitalistiske samfund, og den kan netop varetage dem, fordi den som en særlig institution ved siden af og uden for det borgerlige samfund ikke er underlagt merværdiproduktionens nødvendighed, hvilket enkeltkapitalen er, uanset hvor stor den måtte være. Statens adakvate form i kapitalismen fremtræder derfor som en særlig eksistens over for enkeltkapitalerne og ikke som »monopolernes instrument«. (Dette dog kun i en formidlet forstand).

Men hvilke funktioner varetager staten inden for det kapitalistiske samfund, fordi enkeltkapitalerne ikke formår at varetage dem? Det drejer sig især om fire områder, hvor staten frem for alt er aktiv:

1. tilvejebringelse af almene materielle produktionsbetingelser (»infrastruktur«).

2. skabelse og sikring af de almene retsforhold, som retssubjekternes relationr i det kapitalistiske samfund udspilles i.

3. regulering af konflikten mellem lønarbejde og kapital og i givet fald politisk undertrykkelse af arbejderklassen, og dette ikke blot med retlige men også med politimæssige og militære midler.

4. sikring af den nationale totalkapitals eksistens og ekspansion af det kapitalistiske verdensmarked.

Alle disse funktioner er ganske vist hvad man kunne kalde den borgerlige stats almene karakteristika, men de udvikler sig på kapitalakkumulationens $h i$ storiske grundlag.

1. Lad os nu først se på de materielle produktionsbetingelser. Hvilke almene produktionsbetingelser, staten skal tilvejebringe på et givet tidspunkt, afhænger af kapitaludviklingens historiske stade; betragtet fra den stoflige side er f.eks. jernbanens funktioner i den samfundsmæssige arbejdsproces i dag de samme som for 100 år siden. Alligevel blev jernbanerne drevet privat i det 19. årh., de var en rentabel form for kapitalanbringelse, hvorimod de er en udtalt tabgivende forretning i dag, og dermed udgør de en sfære for den borgerlige stats aktioner.

13. Sml. forlængelsen af arbejdsdagen, skærpet intensivering af arbejdet og som svar herpå arbejderbeskyttelseslovene etc. Se KAPITALEN, Kbh. 1970, 1:2, s. 367 ff. (o.a.) 
Dette er kun et eksempel ${ }^{14}$ på de statslige aktiviteters konkrete historiske betingethed ved tilvejebringelsen af de almene produktionsbetingelser. I almindelighed kan man kun sige, at antallet af nødvendige produktionsprocesser, som staten må overtage eller regulere, må tiltage på grund af profitratens historiske tendens til fald, idet et ledsagefænomen til den jo netop er, at stadig flere produktionsprocesser fremstår som urentable for enkeltkapitalerne (selv om det overfladisk set er af forskellige grunde) og derfor må opgives eller indskrænkes, altså forsvinder fra de gennem konkurrencen formidlede enkeltkapitalers aktionsområde.

For virkeligt at forstå den ovennævnte proces, der kun er tilstrækkelig for de materielle almene produktionsbetingelser og kun vil være tilstrækkelig for statens andre funktionsfelter på en modificeret måde - eller slet ikke - er det derfor nødvendigt at begribe den ud fra den kapitalistiske produktionsproces' dobbeltkarakter som arbejds- og valoriseringsproces (på et samlet samfundsmæssigt niveau). Enkeltkapitalerne kan selv stille $e n$ del af de stofligt-materielle produktionsbetingelser til rådighed, som kræves af de forskellige enkeltkapitalers arbejdsproces med et givet niveau i produktivkræfterne - et niveau, som er påtvunget af konkurrencen (i verdensmålestok). Den ene enkeltkapital producerer som følge heraf forudsætningerne for andre enkeltkapitalers produktion. Denne sammenhæng bliver som kapitalernes indbyrdes samfundsmaessige arbejdsdeling til gennem konkurrencen på markedet. Men en anden del af de stoflige produktionsbetingelser kan ikke produceres af kapitalerne, da deres produktion er urentabel i forhold til de kapitalistiske betingelser, altså valoriseringsprocessen. Således opstår krav i den samfundsmæssige arbejdsproces, der ikke kan opfyldes under den kapitalistiske betingelse: enheden af arbejds- og valoriseringsproces. (Vi vender tilbage til, hvilke betingelser det drejer sig om). Hvad der for enkeltkapitalerne fremtræder som en produktionsforudsætning af denne art, er - set fra arbejdsprocessen - et område, som kapitalerne forsømmer. Det skaber en slags »vacuum«, hvor staten nødvendigvis må træde ind, da den jo ikke er underlagt valoriseringstvangen som enkeltkapital - hvad dette "vacuum« altid er et resultat af. I overensstemmelse hermed er de dele af det samfundsmæssige værdiprodukt, som staten inddrager og giver ud igen, ikke kapital i statens hænder. Derfor fradrages statslige funktioner af denne art altid den givne samfundsmæssige kapitalfond og begronser dermed enkelt kapitalernes kapitalakkumulation. Her har vi således også en forholdsvis virksom grænse for de statlige interventioners omfang: de kan ikke antage så stor et omfang, at den private kapitalakkumulation ligger brak. Denne grænse følger netop af den kendsgerning, at staten er ikke-kapitalist $i$ et kapitalistisk samfund; hvis

14. Hvor meget statens overtagelse af de almene produktionsbetingelser afhænger af et lands historiske tilstand, og hvor lidt den afhænger af en principielt forstået "grad af almenhed« eller »a priori samfundsmæssigt« arbejde i relation til den samfundsmæssige produktion, belyses også af den kendsgerning, at sundhedsvæsenet i USA for allerstørstedelens vedkommende drives privat, i Vesttyskland statsligt, mens en stor del af uddannelsesvæsenet i Japan sågar drives privat. Allerede disse eksempler viser, at generaliseringer på dette felt kun kan føre til fejlslutninger. 
den selv var kapitalist, ville udlæggene til de almene produktionsbetingelser have kapitalkarakter, og dermed ville man ikke kunne se, hvorledes det kapitalistiske samfunds modsætninger skærpes gennem den voksende statslige aktivitet.

Som arbejdsproces behøver den enkeltkapitalistiske produktionsproces altså bestemte forudsatninger for at dens karakter af middel til den enkeltkapitalistiske valorisering skal kunne opfyldes - forudsætninger, som ikke er investeringssfarer for enkeltkapitalerne. Statens almene funktioner består i at varetage disse, hvorved den art og måde, som de varetages på, er historisk bestemt.

Een side af betingelserne for, at kapitalen i stadig ringere grad bliver i stand til at opfylde arbejdsprocessens krav om at være valoriseringsprocessens middel, er karakteriseret ved profitratens historiske tendens til fald. Den anden side følger af produktivkræfternes stigende niveau, som - alment sagt - sprænger den kapitalistiske produktions bornerte side: at være produktion af merværdi. Man må dog her tage hensyn til, at det at fastslå en tendens i kapitalismen kun har mening for så vidt som der tages hensyn til denne tendens' cykliske forløbsmåde. Den nutidige statsdel af nationalproduktet forskydes tilsyneladende naturgroet, i overensstemmelse med produktionens cykliske gang, hvilket er en ret grov indikator på det her omtalte problem. Denne sammenhæng vil blive tydeligere ved behandlingen af problement »stagflation«i 4 . del.

Efter denne grove karakteristik af dette statslige funktionsområde - sikring af de almene materielle produktionsbetingelser - vil vi nu kortfattet gennemgå de øvrige nævnte funktionsområder.

2. Mens de økonomiske forhold er konstitueret som umiddelbare tvangsforhold i de før-kapitalistiske produktionsmåder og endnu delvis er det ved overgangen til kapitalisme, så træder med den industrielle kapitals udvikling statens umiddelbare indgreb i baggrunden; indgreb som i den oprindelige akkumulation var et væsentligt udtryk for den umiddelbare tvang. Statens funktion gælder nu i alt væsentligt skabelsen af de almene forudsatninger for den frie konkurrence samt fjernelse af friktioner gennem dannelsen af almene retsforhold og overvågelsen af deres opretholdelse. ${ }^{15}$ Først gennem regulering af konkurrencens, bytningens og den kapitalistiske ejendoms sfærer frigøres kapitalen i konkurrencen til at kunne fuldbyrde den kapitalistiske tilegnelsesproces kontinuerligt i kraft af sin sikrede ejendomstitel. ${ }^{16}$

15. »Interessen i varehandlens funktioneren, i arbejdsprodukternes valorisering på markedet, fører til retten og til ophævelsen af den politiske resp. statslige vold. Tvangen 'må . . . optræde som en tvang, der udgår fra en abstrakt kollektivperson, der ikke udøves i det individs interesse, som den udgår fra . . men i alle under retforholdet subsumerede individers interesse.' Det ene menneskes magt over det andet bliver i virkeligheden omsat i rettens magt, dvs. som en objektiv, upartisk norms magt.«W. Rosenbaum: Zum Rechtsbegriff bei Stucka und Pasukanis; i: Kritische Justiz, Heft 2/71, s. 156. Primær-citatet stammer fra Pasukanis: Allgemeine Rechtslehre und Marxismus, Frankfurt 1966, s. 123 f.

16. Sml. Grundrisse, s. 542 ff. Her siges det: ». . . den produktion, som er baseret på kapitalen, sætter sig kun i sine adækvate former, såfremt og for så vidt som den frie konkurrence udvikles, thi denne er den frie udvikling af den produktionsmåde, som er baseret på kapitalen; den er den frie udvikling af kapitalens betingelser og den er 
I det borgerlige samfund er den retlige regulering dog aldrig blevet begrænset til konkurrencens sfære alene. »Den anden væsentlige del af det borgerlige samfunds ret organiserer umiddelbart herskabsforholdene, f.eks. i strafferet, handelsret, arbejdsret etc. ${ }^{17}{ }^{17}$ retten kodificerer den borgerlige stat således ikke blot varebesiddernes almene samkvemsbetingelser, men også de almene produktionsbetingelser, arbejdsbetingelser osv. ${ }^{18}$ At staten her bliver aktivt organiserende, har netop sin årsag i konkurrencen, der tvinger kapitalerne som enkeltkapitaler til at handle mod nødvendigheden af at opretholde kapitalforholdet. Det er kun staten, som kan blive aktivt regulerende her, fordi den er en særlig indretning, der ikke er underlagt denne konkurrence. Dens nødvendighed og den her andørte specifikke funktion følger netop af, at staten som organ for den herskende klasse ikke er underlagt enkeltkapitalernes valoriseringstvang, og den kan derfor orientere sig mod alle kapitalers fællesinteresse. Denne egenskab ved staten gør den i stand til at gennemføre og overvåge dels rettens opretholdelse, dels konkurrencens regler, således som det kommer til udtryk i statslige justérkamre, materialekontrolkamre, patentkontorer osv. ${ }^{19}$ Endelig overvåger den også arbejdsaftalen, som jo ikke længere er relateret til varebesiddernes byttehandel, men derimod til produktionsprocessen som den proces, hvor kapitalen udbytter lønarbejdet. ${ }^{20}$

3. Hermed føres vi frem til en kort karakteristik af statens funktioner ved reguleringen af konflikten mellem lønarbejde og kapital. Den almene problematik består netop i, at kapitalforholdet fremtræder i markedets sfære som et forhold mellem grundlæggende lige subjekter, selv om det i det væsentlige er et herskabs- og udbytningsforhold. Da det kapitalistiske samfund er et klassesamfund, får staten - p.g.a. den stadige klassekonflikt og nødvendigheden af at inddæmme den af hensyn til samfundets opretholdelse - også funktioner, hvis indhold må sættes i relation til tilvejebringelse af de almene udbytnings-

den proces, der bestandig reproducerer disse betingelser. Det er ikke individerne, men kapitalen, som er befriet i den frie konkurrence....

17. Rosenbaum, op. cit. s. 159. Selv om betoningen af, at retssystemet ikke blot regulerer bytningens sfære, men også bestemmer produktionsprocessen som kapitalens herskabsområde, grundlæggende set er rigtig, er ligestillingen mellem strafferet, handelsret og arbejdsret dog betænkelig. Det er sikkert ikke tilfældigt, at arbejdsretten som sådan først opstår ret sent historisk, egentlig først i den italienske fascisme, altså i sammenhæng med en »korporativ« defineret stat. Reguleringen af arbejdsaftalen spiller en yderst underordnet rolle i den tyske borgerlige lovbog. At der ikke findes en arbejdslovbog ved siden af den borgerlige lovbog og handelslovbogen ligger netop i, at kapitalen er "produktionsfaktorernes mester « $\mathrm{i}$ arbejdsprocessen og kun lader sig begrænse $\mathrm{i}$ denne funktion $\mathrm{i}$ »undtagelsestilfælde«.

18. Sml. hertil 8. kapitel af KAPITALENs 1. bog (da. 1:2, s. 367 ff.), hvor Marx beskriver indførelsen af 10-timersdagen. Se videre Müller/Neusüss: Die Sozialstaatsillusion und der Konflikt Lohnarbeit und Kapital, i: Probleme des Klassenkampfs, Sonderheft 1, hvor Marx' analyse anvendes eksemplarisk.

19. Også pengemønterne er et eksempel på de statslige aktioner. Oprindelig var de i mange lande et privat anliggende, ligesom seddelbankerne heller ikke var et statsligt anliggende fra begyndelsen. Efterhånden kom den statslige møntprægning til at tjene som garanti for, at vægt og møntudtryk var i overensstemmelse. I USA er Secret Service som et historisk levn endnu i dag underlagt finansministeriet, da S.S. oprindeligt blev oprettet for at afsløre falksmøntnere.

20. Se hertil KAPITALEN, 1:4, s. 820 ff., hvor Marx viser, hvorledes vareproduktionens ejendomslove slår om i kapitalistiske tilegnelseslove (o.a.) 
betingelser, regulering af lønraten og undertrykkelse af klassekamp. Dette funktionsfelt for statslige aktioner er ligeledes et resultat af den historiske udvikling, nemlig et direkte resultat af den herskende klasses modstrategier, som opstod med arbejderbevægelsens udvikling og dens bevidste kampe. Eftersom hele den borgerlige klasse som sådan rammes eller trues i tilfælde af klassekamp kan enkeltkapitalerne derfor ikke individuelt overtage neutraliserings- og undertrykkelsesfunktionerne, ${ }^{21}$ disse bliver mere og mere et område for aktioner fra »det kontor, der ordner den herskende klasses fælles interesser.«

4. Som nationalstat er staten også de nationale enkeltkapitalers sammenføjning overfor andre nationalstater på verdensmarkedet. På dette område ses de statslige funktioner allerførst som statslige: fra sikring af den indenlandske valuta og politiske forbindelser til udlandet til militær sikring af den private kapitalakkumulation og -ekspansion i imperialismens epoke. Udviklingen af funktionsområder, som påhviler staten, er oven i købet regelmæssigt formidlet gennem statens karakter af nationalstat, d.v.s. gennem konkurrence og kamp mellem nationalstater. ${ }^{22}$ Selv om vi har anført statsfunktionerne efter hinanden, så er det dog ikke ud fra en antagelse om, at de virkeligt kan skilles fra hinanden på denne måde. Det er langt snarere sådan, at statens karakter af borgerlig klassestat gennemsyrer alle dens funktioner; de tjener i sidste instans alle til at opretholde og befæste kapitalforholdet som herskabs- og uudbytningsforhold overfor arbejderklassen. Dette kan der ikke abstraheres fra. De problemer, der interesserer her, er, i hvilken udstrækning der i varetagelsen af disse funktioner skabes modsætninger, hvilke grænser statens funktioner hermed bliver underlagt og hvilke problemer, der dermed opstår for kapitalerne, samt endelig hvilke taktiske konsekvenser det må føre til for arbejderbevægelsen.

Resultatet af statens specificering som en form uden for og ved siden af det borgerlige samfund er, at staten må fremtræde for enkeltkapitalerne som den negative skranke for kapitalens valorisering: den indsætter arbejdskræfter til skabelsen af de almene materielle produktionsbetingelser, til opretholdelse af retssystemet, til politimæssig og militær undertrykkelse - arbejdskræfter, som derfor ikke længere står til kapitalens disposition som udbytningsobjekter (selv om arbejdssitua-

21. Her må tages hensyn til en vigtig modifikation. Thi store enkeltkapitaler opretholder også regelmæssigt undertrykkelsesapparater i form af fabriksværn, hvis funktion er entydigt rettet mod at slå klassekamp på fabriksgulvet ned. Eksempler på »fabriksværnenes « overgreb mod demonstrerende og protesterende arbejdere viser entydigt deres karakter af privatarmé for kapitalen. Dobb: Organisierter Kapitalismus, Frankfurt 1966, s. 116-124, behandler de store US-koncerners aktioner under og efter verdenskrisen mod strejkende arbejdere, funktionærer og fagforeninger; disse aktioner afslører enhver talen om idyllen i "New Deal «, i venstrekeynesianisme og i "velfærdsstaten « som elendigt skønmaleri. Sml. også fabriksværnets mord på kammerat Overney på Renault-fabrikkerne i februar 1972, og de vesttyske fabriksværns mange nødretsøvelser, som især blev opdaget under anti-nødretsbevægelsen i 1968, hvorefter de igen har kunnet finde sted i en halvskjult illegalitet. Her viser det sig i øvrigt, at den statslige sfære og den private kapitals ikke kan afgrænses skarpt og entydigt, men derimod går over i hinanden på mange områder.

22. Se hertil Müller/Blanke/Altvater: Kapitalistische Weltmakt und Weltwährungskrise, i: Probleme des Klassenkampfs 1:1971, især s. $112 \mathrm{ff}$. 
tionen betragtet fra arbejderens side er den samme som for de af privatkapitalen anvendte arbejderes) ${ }^{23}$ eller også fastsætter den ydre granser for kapitalens valoriseringstvang gennem begrænsning af arbejdsdagen, gennem retlige skranker osv. På overfladen fremtræder den af staten fastsatte negative valoriseringsskranke for de enkelte kapitaler som skatter, der skal betales, som sociale udgifter osv., altsammen til dækning af »fællesskabets opgaver «, og som videre begrænser den individuelle konsumption og/eller akkumulationen af merværdi. Hvis arbejdsdagens naturlige grænse for arbejdslovgivningen var kapitalens skranke i dens trang til merarbejde, så er grænsen efter arbejdslovgivningen $i$ almenhed sat af staten.

Når staten er bestemt på denne måde - som det kapitalistiske samfunds indretning, uden for og ved siden af samfundet, både på dets grundlag og fremtrædende som den negative valoriseringsskranke - er det klart, at statens historiske funktioner ikke er iboende i den fra begyndelsen af og af sig selv, men netop resultater af kriser i den samfundsmæssige reproduktion, og derfor må være formidlet gennem klassekamp og opgør mellem fraktioner af den herskende klasse. (Men det, at den overhovedet får disse funktioner er begrundet i det kapitalistiske samfunds natur og dets stat overhovedet). Ingen kapital kan af sig selv frivilligt adlyde bestemte, måske objektivt indsete nødvendigheder; konkurrencens tryk vil afholde den fra at gøre det. Ingen kapital vil bifalde en indsnævring af de ydre grænser for kapitalens valorisering, som er sat af staten, uden ydre foranledning; den vil først være parat til det på grund af katastrofer, stridigheder og kampe. Men dette siger også om klassekampen, at den har en vigtig funktion for det kapitalistiske samfunds opretholdelse (naturligvis er dette kun een, her særlig fremhævet side ved klassekampen), idet den hjælper den objektive historiske nødvendighed til gennembrud i kraft af staten.

Som en art empirisk bekræftelse på denne tese kan fremhæves, at statens andel af nationalproduktet (som er en grov indikator på statens funktioner i samfundet) frem for alt er steget som følge af klassekampe efter 1. verdenskrig, og efter eller som forberedelse til verdenshistoriens store katastrofer, verdenskrigene. Selv om Adolph Wagner ganske vist meget alment og dårligt begrundet taler om »loven om den tiltagende statsaktivitet«, hvorved han snarere udtrykker en formodning end fastslår en tendens,${ }^{24}$ så kan man dog ikke benægte det faktum,

23. Dette betyder ikke, at arbejdsbetingelser og løn er identiske for den statslige og den private sektor. Det er langt snarere sådan, at arbejdere og funktionærer i den offentlige sektor hyppigt er de dårligst lønnede og arbejder under de dårligste arbejdsbetingelser. Således er det i England, Frankrig og BRD. Dette svarer også til Marx’ tese, at de uproduktive arbejdere - hvilket de statsansatte, -funktionærer og -arbejdere jo er - som regel underholdes af de produktive arbejderes værdiprodukt. For størstedelens vedkommende finansieres de af merværdien, hvis størrelse dermed sætter grænsen for deres løn. Grænserne for den statslige aktivitet udtrykker sig derfor for de enkelte statsansatte som dårligere lønninger og arbejdsvilkår.

24. Se Adolp Wagner: Das Gesetz der zunehmenden Staatsätigkeit, optrykt i »Finanztheorie«, op. cit. s. $241 \mathrm{ff}$. »Opfattet nationaløkonomisk betyder denne lov en absolut og selv en relativ udvidelse af den offentlige, især af det statslige fællesskabs organisationsform ved siden af og i stedet for den privatøkonomiske inden for samfundsøkonomien ...«(s. 241). 
at statens andel i Tyskland er steget fra 15 til 40\% i dette århunhundrede. Her er det bemærkelsesværdigt, at statsudgifterne »er af mindre omfang i faser med vedvarende økonomisk vækst end i perioder med svagere udvikling, medmindre der hersker depression med negative vækstrater i nationalproduktet (ekspansion). I sidstnævnte tilfælde siger kurven for dens andel stærkt. . . ${ }^{25}$ Hermed siges blot, at statsaktiviteten - for så vidt som den er forbundet med udgifter - følger kapitalens valoriseringsbetingelser. Er disse gunstige, vil den andel, som produceres af kapitalen til at gennemføre den samfundsmæssige arbejdsproces stige eller i hvert fald ikke falde. Slår profitratens tendens til fald derimod igennem i konjunkturafmatningsfasen, så vil statsandelen vokse, delvis helt naturligt som en følge af de voksende reguleringsudgifter, men herom senere.

På det kapitalistiske samfunds grundlag er staten altså på en vis måde komplementær til enkeltkapitalerne, hvorved den givne »komplementaritet « i de statslige funktioner er historisk bestemt. Dette kommer meget tydeligt til udtryk selv i teorierne om »statsinterventionisme« fra forskellige lande og forskellige epoker. Hvor Adam Smith og i modificeret form også Ricardo krævede, at statsfunktionerne skulle indskrænkes til militær, politi, uddannelse og ret, mens den »naturlige« samfundsudvikling skulle overlades til de private kapitaler selv, så tilskrev det 19. århundredes tyske finansvidenskabs teoretikere (A. Schaeffle, L. von Stein, A. Wagner) staten en aktiv rolle ved kapitaldannelse og -akkumulation. Englands og Tysklands forskellige situation med hensyn til kapitalakkumulation og konkurrence på verdensmarkedet udtrykkes eksakt i denne teoretiske forskellighed. Det viser sig også her, at samfundsmæssige funktioner altid først opstår som statslige funktioner, når de ikke bliver - eller kan blive - gennemført af enkeltkapitalerne. Statens specificering ligger således grundfastet $i$ kapitalforholdets »natur«, men dannelsen af den virkelige stat fuldbyrdes under et lands gione historiske betingelser $i$ en bestemt epoke; man kan derfor også først afgøre, hvilke almene produktionsbetingelser, der er »almene« i den forstand, at de må fremstilles af private kapitaler på grundlag af et lands givne historiske situation. Dette problem vil vi analysere nøjere i det følgende afsnit med de almene materielle produktionsbetingelser som eksempel.

\section{Fremstillingen af almene materielle produktionsbetingelser gennem staten}

Vi har frem for alt set grundene til statens specificering i frembringelsen af de almene produktionsbetingelser. Nu bliver det nødvendigt at gå ind på de materielle forudsætninger for produktionen og spørge, hvad der gør, at de produceres af staten og ikke af private kapitaler. Hvis man går ud fra en almen, gensi-

25. Horst Claus Recktenwald, Ergänzung: Zur Wirksamkeit des Wagnerschen Gesetzes, i: Finanztheorie, op. cit. s. 246. 
dig afhangighedssammenhang i et samfund, forsvinder skellene mellem almene og særlige produktionsbetingelser, samt mellem almene, af kapitalen producerede produktionsbetingelser og almene, af staten producerede betingelser. ${ }^{26}$

Til de funktioner, som ikke eller ikke længere eller endnu ikke kan udfyldes af kapitalen, hører eksempelvis: frembringelse af et kommunikationssystem (gader og veje, kanaler, telegraf og post), frembringelse af en kvalifikationsstruktur, som er adækvat i forhold til produktivkræfterne (uddannelsessystem), reparation af arbejdsevnen (sundhedsvæsen), vandforsyning, kloakering og renovation m.m. Grundene er vidt forskellige til, at det ikke lønner sig at drive disse processer kapitalistisk. De ligger i hvert fald ikke i disse indretningers stoflige egenskaber. De kan ligge i, at kapitaludlægget er for stort for en enkeltkapital, og at omslagstiden (arbejdsperiode, produktionstid eller omløbstid) er for lang; eller i, at resultaterne af disse produktionsprocesser ikke har en umiddelbar varekarakter (kvalifikationer, forskningsresultater); eller i, at markedet (det samfundsmæssige behov) er for lille i absolut størrelse for en rentabel produktion, dvs. for realiseringen af den udlagte kapitalværdi plus merværdi; eller i, at kapitalen ikke stiller sig tilfreds med en profitrate under gennemsnittet, selv om den måtte være positiv, fordi der findes mere profitable investeringssfærer, f.eks. i udlandet.

Jo længere arbejdsperiode og jo mere langvarig tilbagestrømningen af kapital er, desto større er det øjeblikkelige kapitaludlæg, og desto mere usikkert er en opnåelse af gennemsnitsprofitraten. Hvis der til sådanne kapitaludlæg yderligere kommer, at produktionsprocessens resultater ikke kan antage varekarakter, altså at ydelserne f.eks. fra en vej kan eller skal stå til alles rådighed, så kan sådanne anlæg ikke drives kapitalistisk. Kapitalistisk drift vil her sige: udbytning af arbejdskraften til produktion af merværdi, dvs. produktion for en valorisering af kapitalen. Men hvis nu nødvendigheden af en udbygning af »infrastrukturen« er stor nok, således at der må bekostes udgifter hertil,

»så vælter kapitalen dem over på statens skuldre eller - hvor staten traditionelt indtager en overordnet stilling i forhold til kapitalen - har den endnu privilegiet eller viljen til at tvinge helheden til [at anbringe] en del af deres revenu, ikke af deres kapital, i sådant almen-nyttigt arbejde, som samtidig fremtræder som produktionens almene betingelser

26. Spørgsmålet om gensidig afhængighedssammenhæng spiller en stor rolle i den borgerlige vækstteori. Videst går »balanced growth«-retningen, hvis mest betydningsfulde repræsentant, P. N. Rosenstein-Rodan, skriver: Komplementariteten gør i en vis forstand alle industrier til 'basis'industrier.« (Problems of Industrialization of Eastern and South-Eastern Europe, i: Agarwale/Singh: The Economics of Underdevelopment, N.Y. 1963, s. 252). Anvendes tesen på vores problem, implicerer den en antagelse om, at 1) enhver produktion frembringer almene produktionsbetingelser og 2) som en følge af den almene interdependens behøves ingen yderligere kvalificeringer mellem stat og privat kapital. Lidt anderledes, mindre naivt, men stadig på gensidig afhængighedssammenhængstesens grundlag argumenterer W. Wittmann (i: Staatliche Aktivität, wirtschaftliche Entwicklung und Preisniveau, Zürich 1965, s. 22): „Det er for det første klart, at de private investeringer alene, som skaber yderligere produktionskapacitet, ikke er tilstrækkelige til at sikre den langfristede økonomiske udvikling ... For at forhindre flaskehalse i den økonomiske udvikling mest muligt er det nødvendigt, at investeringer i socialkapitalen $(=$ de almene materielle produktionsbetingelser, E.A.) holder trit med totaludviklingen .... 
og derfor ikke som en særlig betingelse for en eller anden kapitalist; og så længe kapitalen ikke antager form af et aktieselskab, søger den altid kun de særlige betingelser for sin valorisering; de samfundsmæssige betingelser skubber den over til hele landet som landets behov. Kapitalen overtager kun de foretagender, som i dens forstand er fordelagtige. ${ }^{27}$

At denne fordelagtighed ikke længere er givet selv for aktieselskaber, der står ansigt til ansigt med en tendentielt faldende profitrate og produktivkræfternes stigende niveau, viser jernbanevæsenets udvikling: jernbanen, som oprindelig var en yderst rentabel investeringssfære, er i dag en tabsforretning i den kapitalistiske kalkulation. ${ }^{28}$

For at undgå misforståelser må man tale om produktion og drift af infrastrukturelle anlæg. Det er klart, at produktionen af en vejbro er nøjagtig lige så "produktiv«, dvs. profitabel, som produktionen af en maskine eller et sæt tøj. Alle de 3 produkter, som her er valgt som eksempel, bliver produceret som varer og byttet på et marked; men formen er forskellig. Klædeproducenten leverer til et massemarked, og når en køber har erhvervet sig klædedragten, har kapitalisten fået erstattet sin udlagte kapital, profit iberegnet, og køberen har købt en konsumvare for en del af sit revenu. Klædedragten interesserer fra nu af ikke længere køberen som værdi, men kun som brugsværdi; men brugsværdien er ligegyldig for den økonomiske analyse så længe, den ikke selv er formbestemmende hvilket netop er tilfældet efter fuldendt bytning. Maskinproducenten producerer derimod som en følge af en maskinkøbers bestilling. Men dette ændrer intet ved, at han stadig producerer for et af ham normalt ubekendt marked, og med maskinens omsætning i penge fuldender hans kapital en cirkulationsakt. Heri adskiller han sig heller ikke fra klædeproducenten. Men maskinkøberens tilfælde ser anderledes ud end klædekøberens. Han køber ikke maskinen med sit revenu; ${ }^{*}$ men med sin pengekapital, som han lægger ud for at indlede eller fortsætte en produktionsproces. Maskinen bliver altså forvandlet til en del af den produktive kapital; den er et produktionsmiddel i kapitalform og fortsætter i overensstemmelse hermed cirkulationen som kapital. Lad os nu se på producenten af broen (f.eks. et entreprenørfirma). Også her produceres en vare (på bestilling, mod forudbetaling osv.) med en specifik karakter; ved salget realiserer også denne producent den indskudte værdi og merværdien, ellers ville han undlade at producere. Men han bytter den ikke mod en kapital i pengeform,

27. Grundrisse, op. cit., s. 430 .

28. Et amerikansk eksempel på krisers udvikling inden for jernbanevæsenet og statens indgriben findes i artiklen »The long-run decline in Liquidity«, Monthly Review, vol. 22/4, sept. 1970, s. 1-17; spec. s. 14-15. (o.a.)

* revenu: Delingen af merværdien i revenu og kapital udvikles af Marx i 1. bind af 'Kapitalen', især på siderne 835-858. "En del af merværdien konsumeres af kapitalisten som revenu, en anden anvendes som kapital, dvs. akkumuleres« (s. 835). »Konkurrencen tvinger kapitalisten til hele tiden at udvide sin kapital for at bevare den, og han kan kun udvide den gennem progressiv (fremadskridende) akkumulation.«(s. 837). Kapitalen, Kbh. 1970 1:4. (o.a.) 
derimod mod revenu, som staten giver ud. Revenuet får staten gennem skatter, afgifter osv. for igen at give det ud for at opføre almene produktionsbetingelser. Fremstillingen af broen er altså fuldt ud profitabel for kapitalen, men ikke dens anvendelse. Der er ingen kapitalist, der ville skyde sin kapital ind for at bygge en vejbro selv. Afgørende for om staten overtager bestemte produktionsbetingelser eller ej er altså, 1) om kapitaludlægget lønner sig kapitalistisk og 2) om den givne produktionsbetingelse virkelig er nødvendig for den samfundsmæssige arbejdsproces. (Vi har allerede tidligere betonet, at denne nødvendighed ikke alene erkendes ud fra en indsigt, men bliver påtvunget af kampe, konflikter, katastrofer og kriser). Almene materielle produktionsbetingelser lader sig altså meget vel fremstille profitabelt, men kan under enkeltkapitalistiske aspekter ikke drives profitabelt.

Det forholder sig anderledes på uddannelsesområdet. Der gælder det samme for den materielle side af dette område som for den nævnte bro: skolebygninger, undervisningsmateriale osv. kan fremstilles kapitalistisk. Men det kan produktionen af kvalifikationer ikke i større omfang. De bliver allerede fremstillet i statslige institutioner, mens deres anvendelse sker som et stofligt element $i$ enkeltkapitalisternes variable kapital. Kvalifikationer byttes som regel mod kapital på arbejdsmarkedet som et iboende kundskabselement i arbejdskraften. Denne forskel mellem trafikvæsen (og bygning af skoler) på den ene side og uddannelsesområdet på den anden er graverende. Alle omkostninger til infrastruktur finansierer staten af et lande revenu, og de går som følge heraf i hvert fald delvis fra i den akkumulationsduelige del af merværdien. Men omkostninger til bygning af skoler og broer tilflyder enkeltkapitalerne igen, og de bliver på denne måde i stand til at valorisere deres kapital, idet kapitalværdiens cirkulation hermed lykkes. Udgifterne til produktionen af kvalifikationer - frem for alt til lærere - tilflyder dog ikke enkeltkapitalerne; de muliggør snarere eksistensen af et lag, der formindsker kapitalens udbytning af et givet arbejdstidforhold i samfundet. Dette gælder først rigtigt for de elever og studenter, som under deres uddannelsestid ikke udfører produktivt arbejde, og som derfor ikke alene for en tid er unddraget kapitalens herredømme, men som også efter uddannelsestiden kun kan møde kapitalen på arbejdsmarkedet med en højere værdi af deres arbejdskraft - som en følge af de større omkostninger, der er gået til deres uddannelse - uden at man kan slutte heraf, at der deraf følger en højere værdidannende potens i deres arbejde. Udgifter til uddannelsessektoren går således ikke alene fra i kapitalens merværdi, men forhøjer - hvis de stiger - også altid arbejdskraftens værdi og formindsker dermed merværdiraten, alt andet lige. På den anden side producerer læreren med sit arbejde de almene kvalifikationer, som er en betingelse dels for, at arbejdsprocessen overhovedet kan finde sted som middel for valoriseringsprocessen, og dels for, at den kapitalistiske produktion og kapitalforholdets reproduktion overhovedet er mulig. Kapitalen kan kun finde sig til rette med at finansiere uddannelse- 
området på grund af denne side af læreraktiviteten. De enkelte 'infrastrukturområder' må altså ikke alene holdes skarpt adskilt efter deres stoflige side, men også efter deres stilling i den kapitalistiske reproduktionsproces. ${ }^{29}$

Eftersom kapitalen enten ikke er i stand til at engagere sig eller kun kan gøre det utilstrækkeligt af de her beskrevne grunde, vil staten netop skulle forestå produktionen af infrastrukturindretningerne, fordi den ikke er tvunget til at producere kapitalistisk: dens fonds stammer jo fra landets revenu. På den anden side vil kapitalen sætte sig til modværge, hvis staten ville overtage produktionsprocesser, som trods alt fremstår som udbyttegivende for kapitalen under dens givne sarsynsvinkel. Thi for det første ville det betyde en formindskelse af det i kapitalens betydning uproduktive arbejde og for det andet fjernelsen af en konkurrence, der ikke behøver at stræbe mod en maksimal selvvalorisering af et kapitaludlæg. [...]

Staten er i sin funktion ikke alene regulator af den kapitalistiske produktionsproces, men hjælper kapitalen frem til sin gennemsnitseksistens som totalkapital i kraft af den funktion, som resulterer af statens særlige eksistensform. Staten sikrer de almene produktionsbetingelser ved at overtage alle de stoflige processer, der ikke vil kunne drives kapitalistisk. Dens funktion som stat under kapitalismen: sikring af grundlaget for udbytning af arbejderklassen, består netop i at overtage ikke-kapitalistiske produktionsprocesser i eget regi og i organisatorisk at regulere de betingelser (retsforhold osv.), der virkelig angår hele kapitalistklassen og ud over denne hele samfundet, samt at opretholde et magtapparat udadtil og indadtil. Kun således kan den opfylde sin funktion som stat på det kapitalistiske samfunds grundlag. For at udtrykke det tydeligere: når vi går ud fra den »ensartede mekanisme, der sammenfatter stat og monopoler «, kan vi kun beskrive dens funktionsmåde på den måde, at staten skal frembringe de produktionsbetingelser, som opstår af krav fra arbejdsprocessens produktivkræfter, og som ikke kan frembringes af kapitalen på grund af de kapitalistiske produktionsforholds bonerthed. Staten sikrer kapitalforholdet, idet den handler ikkekapitalistisk, således at man ikke kan tale om »kapital« ved de almene produktionsbetingelser, som staten har frembragt. Det er således unøjagtigt at tale om "statskapital « uden at differentiere mellem udgifter til infrastruktur og »erhvervskapital«, og direkte forkert at påstå: »Den imperialistiske stat står ikke kun over for arbejderne og de ansatte i det umiddelbare statslige område som kapitalist . . ..$^{30}$ Hvis staten opfører sig som kapitalist, kan dette kun for-

29. I den borgerlige økonomi henhører alle infrastrukturområder under samme begreb. Udgifter til trafikanlæg, energiforsyning, vandforsyning, uddannelse, justits, politi og forvaltning er i vores mening . . komplementærinvesteringer ... «W. Weber, op. cit. s. 306. Det samme hos Wittmann, op. cit., og Stohler: Zur rationalen Planung der Infrastruktur, i: Konjunkturpolitik, 1965, og hos de fleste andre forfattere. Et fuldstændig meningsløst kapitalbegreb modsvares altså af et fuldstændig meningsløst investeringsbegreb, som alle udgifter subsummeres begrebsløst under uden at reflektere deres forskellige økonomiske karakter.

30. Der Imperialismus in der BRD, Frankfurt 1971, s. 366. Man må dog fremhæve, at denne tese ikke 
klares ud fra et lands særlige historie, altså ud fra særlige historiske betingelser. Dens adfærd som virkelig kapitalist vil altid ske igen i undtagelsessituationer, som under 1. Verdenskrig i Tyskland (begrebet »statskapitalisme« stammer fra denne periode), delvis i den tyske fascisme eller i Italien og Frankrig, samt efter 2. Verdenskrig. Men dermed er den kapitalistiske produktionsmåde dog på ingen måde ophævet, selv om væksten i de direkte statsligt drevne produktionsprocesser er et entydigt indicium på den udviklede kapitalismes opløsningsfonomener, på dens stagnation og de manglende "private« investeringsmuligheder. ${ }^{31}$

Således handler staten altså som ikke-kapitalist - når man ser bort fra de nævnte historiske særtræk - og indsnævrer som sådan den private kapitalakkumulations og -reproduktions felt. Hvis staten selv var kapitalist, så ville den netop udvide kapitalproduktionens sfære og udtrykke alt andet end det borgerlige samfunds opløsningsfænomener. For så vidt er teorien om den statsmonopolistiske kapitalisme selvmodsigende, da den på den ene side hævder, at staten selv fungerer som kapitalist, og på den anden side taler om imperialismens almene undergangstendenser. (Vi benægter den første tese, ikke den anden).

\section{Ekskurs til fremstillingen af de almene produktionsbetingelser $i$ den asiatiske produktionsmåde}

Det er ikke noget nyt i menneskehedens historie, at bestemte opgaver i den samfundsmæssige reproduktionsproces bliver varetaget af staten eller af en over den umiddelbare producent overordnet enhed. I denne sammenhæng er den asiatiske produktionsmåde særlig vigtig. Den er karakteriseret ved, at især den landbrugsmæssige produktions komplicerede vandingsanlæg vedligeholdes og udvides af den overordnede enhed, staten, hvilket er tilfældet i Indien, i Kina og i visse områder i Afrika og Latinamerika før kolonitiden. Men her drejer det sig netop ikke om særlige funktioner uden for og ved siden af samfundet, men om samfundsmassige funktioner som sådan. Vandingsanlæggene bliver ikke bygget for at give enkelte kapitaler en valoriserings-basis, men er en del af en samfundsmassig arbejdsproces, der $i k k e$ er et middel for de mange valoriseringsprocesser. I den asiatiske produktionsmåde er den kunstige vanding den grundlæggende materielle betingelse for samfundets og samfundsmedlemmernes reproduktion; disse funktioner udøves af den overordnede enhed, fordi de ikke kan udøves på landsbybasis eller gennem den enkelte gens. Dette er noget grundlæggende andet end betydningen af »fællesskabets opgaver « i kapitalismen, hvor de netop overtages af staten, fordi udførelsen af disse funktioner ikke afkaster profit og derfor er uden interesse for enkeltkapita-

fastholdes ensartet hele værket igennem, ligesom en udtalt begrebsmæssig uskarphed gør sig gældende i hele dette »standardværk «.

31. Paul Mattick: Gemischte Ökonomie und ihre Grenzen; i: Soziale Revolution, nr. 2/1971, s. 46 ff. 
lerne. Forskellen ligstaten på forhånd. For kun således kan forholdet mellem stat og samfund forger altså ikke i den stoflige side, almene produktionsbetingelser lader sig ikke begrunde stofligt. Forskellen ligger i produktionsmådens form, som først i kapitalismen er karakteriseret ved produktionsprocessens dobbeltkarakter. Først her kan den ejendommelige deling forekomme mellem kapitalistisk gennemførte produktionsprocesser og ikke-kapitalistisk, dvs. statsligt gennemførte produktionsprocesser, altså delingen i samfund og stat i form af statens særtræk. I den asiatiske produktionsmåde kræver den samfundsmæssige arbejdsproces derimod direkte varetagelse af bestemte funktioner, uden at todelingen af disse funktioner kan forekomme ligesom i kapitalismen. I relation til de samfundsmæssige krisers problematik viser forskellen på asiatisk produktionsmåde og kapitalisme sig slående: i den asiatiske produktionsmåde er det oplosningen af den centrale magt eller kolonialherrernes knusning af denne magt, og forsømmelsen af centrale opgaver som vejbygning og vanding, der fører til denne samfundsforms opløsning; i kapitalismen er statens voksende opgaver - dannelsen af den såkaldte »blandøkonomi« - netop en fremtrædelsesform for dette samfunds opløsning. Her bliver det således tydeligt, at enhver analyse af »staten « altid må betyde staten i en bestemt samfundsformation; generaliseringer er umuligt.

\section{Regulering af kriser gennem staten}

I fremstillingen af statsfunktionen, altså sikring af de almene produktionsbetingelser, især af materiel art, har vi allerede fremhævet, at staten er underlagt de nødvendigheder, som resulterer af arbejdsprocessen, og de grcenser, der skyldes kapitalens valoriseringstvang. Den får altså ikke overdraget varetagelsen af funktioner som et resultat af en planlægningsproces for samfundet - en planlægningsproces, som er fri for disse problemer ligesom i et socialistisk samfund; disse funktioner påtvinges langt snarere samfundet - og derefter staten - $\mathrm{i}$ krisefyldte situationer, gennem konflikter, kampe, katastrofer, skader osv. Derfor fremstår staten ikke først som kriseregulator, som mester $i$ krisemanagement eller som »senkapitalistisk velfærdsstat «, ${ }^{32}$ hvilket en nyere retning af statsteorien mener, fremfor alt repræsenteret ved Habermas og Offe samt Hirsch m.fl.. ${ }^{33}$ men den er som en historisk tilbleven stat selv resultat af historiske, samfundsmæssige kriser og præget heraf. Det ville dog føre for vidt at eftervise denne prægning i detaljer her, da det ville betyde, at man skulle behandle statsformerne, statsapparatets personelle side og deres konkrete historie; men det forekommer mig uhyre vigtigt med denne henvisning for at kunne forebygge fejltagelser i undersøgelsen af staten og dens funktioner, som meget let kan

32. Claus Offe: Politische Herrschaft und Klassenstrukturen - Zur Analyse spätkapitalistischer Gesellschaftssysteme: i: Politikwissenschaft, Frankfurt 1969, s. 163.

33. Vi skal ikke her diskutere de nævnte forfatteres teorier. (Se herom: Die Sozialstaatsillusionen .... Probleme des Klassenkamps, Sonderheft I; eller: Sozialistische Politik 6/7 og 14/15, o.a.). 
tilskrives stås rigtigt, dvs. ikke blot som et forhold, hvor staten er regulator, hvor samfundet er et rent objekt for reguleringen i dets funktionsområder, og hvor dette samfund skulle kunne aktiviseres gennem politiske gruppers indflydelse på statsapparatet.

Vi skal derfor nu forsøge at analysere statsfunktionerne ud fra samfundets $ø$ konomiske modsigelser og finde statens grundlæggende vanskeligheder i disse modsigelser. Vi vender os dermed mod et statsligt funktionsområde, som indtil nu ikke er blevet berørt i sine særtræk, og som i det mindste siden den »keynesianske revolution « har fået en stadig større betydning, hvilket ikke mindst af denne grund har ført til fejlvurderinger af statsinterventionismens virksomhed. For at kunne vurdere mulighederne for statsinterventionisme er det dog nødvendigt først at opspore krisernes årsager i den samfundsmæssige struktur og undersøge deres funktioner.

\subsection{Krisens funktion $i$ det kapitalistiske samfund}

På det mest abstrakte plan er krisens funktion dobbelt bestemt: (1) »I verdensmarkedskriserne bringes den kapitalistiske produktionsmådes modsætninger og modsigelser til udbrud . . «. ${ }^{34}$ Kriser er altså intet andet end modsigelser i den kapitalistiske produktionsmåde, der er skarpet til udbrud. (2) »Det er netop i krisen, deres enhed (af kapitaludviklingens og bytningens gensidigt selvstændiggjorte momenter - E.A.) bekræfter sig, det forskelliges enhed. ${ }^{35}$ Kriser implicerer også altid en midlertidig losning af modsigelserne, foreningen af de selvstændiggjorte momenter, og de frembringer dermed altid grundlaget for en ny periode af den kapitalistiske akkumulation. Krisen er som modsigelsernes tilspidsede form samtidig det, som i den borgerlige økonomi omskrives til begrebet »renselseskrise«. Derfor findes der heller ingen »absolut undtagelsesfrie tilstande for den kapitalistiske økonomi. Kapitalismen bryder heller ikke sammen af sig selv i den marxske akkumulations- og kriseteori, men finder muligvis sin ende i de politiske aktioner, som er blevet udløst gennem krisen . . . ${ }^{36}$ Det følger videre af krisens dobbelte funktion, at den kapitalistiske akkumulation må bevæge sig cyklisk; akkumulationens immanente modsigelser udvikles periodisk frem til krisen. Krisen renser igen de selvstændiggjorte momenter, der ligger til grund for kriserne, og indleder dermed en ny opgangsfase - frem til fornyet krise. I modsætning til den borgerlige økonomi opfattes den industrielle cyklus af Marx og marxisterne dermed ikke som en konjunkturcyklus med efterfølgende, grundlæggende set ligevægtige faser, men derimod som en krisecyklus, da krisen jo er det »knudepunkt«, som kapitalismens modsigelser koncentreres i. Det er således også krisen, dens udstrækning, dens længde, der i vidt om-

34. Marx: Theorien über den Mehrwert, MEW 26.2 s. 500.

35. ibid., s. 501.

36. Mattick, op. cit. s. 53. 
fang bestemmer karakteren af de andre faser i den industrielle cyklus. Det får endnu en konsekvens for analysen: kriseanalysen kan ikke begynde med krisens fremtrædelsesform, men må - hvis den virkelig vil begribe krisens karakter of funktion - forklare og begrunde kapitalismens grundlæggende modsigelser, hvorfor og under hvilke omstcondigheder de udvikles til en krise. ${ }^{37}$ For at vise dette eksemplarisk i al korthed skal vi gå over til Marx’ fremgangsmåde i »Kapitalen«.

\section{Ekskurs tilforholdet mellem modsigelse og krise $i$ "Kapitalen"}

I denne fremstilling må to forhold holdes ude fra hinanden: ( 1 ) en skærpelse betyder ikke en tilspidsning af modsigelser. Ikke alle modsigelser implicerer nødvendigvis krisen. Modsigelse og krise er ikke identiske. (2) Skærpelse betyder en selvstændiggørelse af de modstående sider, som konstituerer modsigelsen. Dette kan forklares især ud fra de tre første kapitler i Kapitalens bind 1. Herfra kan følgende forkortede argumentationskæde udvikles: varen fremstår som en enhed af brugsværdi og værdi. Denne kvalitet får den dog kun, fordi det arbejde, der medgår til dens produktion, selv har dobbeltkarakter som konkret nyttigt og abstrakt alment arbejde. Eftersom varen bliver produceret med bytning for øje og dette mål med vareproduktionen gør varen til vare allerede i produktionen og ikke først i bytningen - fremstiller arbejdet sig samtidig som privat (produktion af den enkelte vare) og samfundsmæssigt (produktion for bytning mod varer, der er fremstillet af andre producenter). Arbejdets samfundsmæssige karakter er igen dobbelt bestemt: for det første gennem den gennemsnitligt samfundsmæssigt nødvendige arbejdstid, der skal anvendes til produktionen, og for det andet gennem det samfundsmæssige behov for den producerede vare. Her er modsigelsen mellem produktion og realisering allerede indeholdt $\mathrm{i}$ kimform, som først behandles nøjere i Kapitalens 3. bind. Produktion for bytning resulterer i varens fordobling i vare og penge. Når en vare er udskilt som almen ækvivalent over for alle andre vareværdier, får vareværdien en dobbelt eksistens:

»Efterhånden som udvekslingen i historiens løb udvides og uddybes, udvikles den modsætning mellem brugsværdi og værdi, som slumrer i varens natur. Behovet for i det indbyrdes samkvem at have et ydre udtryk for denne modsætning presser på for at give vareværdien en selvstændig form, og dette virker uden rist eller ro, indtil den selvstændige form endelig opnås gennem tvedelingen af varen i vare og penge. I samme grad som arbejdsprodukterne bliver til varer, bliver en vare forvandlet til penge.. ${ }^{38}$

Pengene er foreløbig intet andet end »den nødvendige fremtrædelsesform for varernes iboende værdimål: arbejdstiden $«{ }^{39}$ Varens fordobling i vare og penge

37. Sml. indledningen til Oelssner: Die Wirtschaftskrisen, Reprint Frankfurt 1971.

38. Kapitalen, op. cit., 1:1, s. 189.

39. ibid. s. 197. 
frembringer således pengenes funktion som vardimål. Men i denne funktion tjener pengene kun som forestillede, ideelle penge; varen har kun et pengeudtryk, en pris. Vareværdierne er kun forvandlet i forestillede guldkvanta. Varerne udsiger i deres pengeudtryk kun, hvad de er værd, og pengene tjener her som »regnepenge«. Varens fordobling i vare og penge står endnu kun fuldt og helt i relation til varen: den har en bestemt værdi, der er knyttet til den som dens pengeudtryk, dens pris; pengene er endnu ikke i virkeligheden stillet overfor varen som den pris, som den skal realiseres til. Men: »Prisformen indbefatter . . . denne afhændelse ${ }^{40}{ }^{4}$ Pengene bliver derfor i cirkulationen reelt til bytteværdi, som varen reelt må byttes mod: salge. Pengene har ganske vist ingen anden brugsværdi end den at kunne indløses mod en anden vare som brugsværdi: $k ø b e$.

"Varens udvekslingsproces foregår altså i to modsatte og hinanden kompletterende metamorfoser - forvandling af varen til penge og disses forvandling tilbage til vare. Momenterne i varemetamorfosen er samtidig varebesidderens transaktioner - salg eller udveksling af varen med penge; køb eller udveksling af pengene med vare, og enheden af begge akter: sælge for at købe.«11

Så snart den i varen indeholdte modsigelse mellem brugsværdi og værdi fremtræder, som en ydre modsætning mellem vare og penge, og det vareproducerende arbejdes samfundsmæssige karakter viser sig i, at varen reelt må byttes mod penge - d.v.s., at dens værdi må antage pengeform - ja, så er muligheden tilstede for, at denne byttehandling ikke lykkes.

»Ingen kan sælge, uden at en anden køber. Men ingen behøver straks at købe, fordi han selv har solgt. Omsætningen sprænger de tidsmæssige, lokale og individuelle skranker for produktudvekslingen, netop fordi den spalter den hidtidige umiddelbare identitet mellem afhændelsen af ens eget og modtagelsen af et fremmed arbejdsprodukt op i modsætningen mellem salg og køb. At sige, at disse to uafhængige og indbyrdes modsatte akter udgør en indre enhed, er det samme som at sige, at deres indre enhed udtrykker sig i ydre modsætninger. Hvis de to processer, salg og køb, der egentlig er uselvstændige, fordi de kompletterer hinanden, holdes adskilte og selvstændige, vil deres enhed på et vist tidspunkt gøre sig gældende med voldsomhed gennem en - krise ....42

De immanente modsigelser i varen får deres »bevægelsesformer « i varemetamorfosens modsætninger. Disse bevægelsesformer »indeholder derfor muligheden, men også kun muligheden for kriser «. ${ }^{43}$ Dette betyder, at muligheden for kriseudbrud ikke ligger på alle modsigelsesplaner, men derimod at modsigelserne selv må have fundet bevægelsesformen, hvori deres momenter er betinget som ydre modsætninger, som også kan selvstændiggøres. Det er følgelig ikke et tilfæl-

40. ibid. s. 206.

41. ibid. s. 209.

42. ibid. s. 218.

43. ibid. s. 219. 
de, at Marx først omtaler krisen, når den immanente modsigelse i varen mellem brugsværdi og værdi er udviklet som varemetamorfosens nødvendighed, hvorved den form er begrundet, som modsigelsens momenter overhovedet kan selvstændiggøres realt i overfor hinanden. Først her kan man tale om muligheden for krisen:

»Muligheden for krise, for så vidt som den viser sig i metamorfosens simple form, fremkommer altså kun derved, at de formforskelle - faser - som den gennemløber i sin bevægelse, for det første er nødvendige gensidigt kompletterende former og for det andet andet på trods af denne indre nødvendige samhørighed eksisterer som ligegyldige over for hinanden, som adskilt i tid og rum, som uafhængige dele af processer og former, der ikke blot kan, men også er adskilt fra hinanden. Muligheden ligger altså alene i adskillelsen mellem salg og køb. Det er dog kun i sin form som vare, at varen må gennemgå alle disse besværligheder. Så snart den har pengeform, er den ude over vanskelighederne ... Verdensmarkedskriserne må altså opfattes som den reelle sammenfatning og voldelige udligning af alle den borgerlige økonomis modsigelser. De enkelte momenter, som således sammenfattes i disse kriser, må altså fremgå i og udvikles af enhver af den borgerlige økonomis sfærer, og efterhånden, som vi trænger dybere ind i dem, må vi på den ene side udvikle nye bestemmelser af disse modsigelser og på den anden side eftervise deres mere abstrakte former som gentagende, men også eftervise, at de bevares i deres mere konkrete former. - Man kan altså sige: i sin første form er krisen selve varens metamorfose, det at salg og køb falder fra hinanden ... « $\ll^{44}$

Muligheden for krise ligger altså i adskillelsen mellem salg og køb. Denne bevægelsesform for varens immanente modsigelser må først være udviklet for, at man overhovedet kan tale om krisemulighed. Og herudover er denne mest agstrakte, mest almene form uden krisens indhold indeholdt i den mere konkrete form, som krisen bevæger sig realt $i$.

Når krisen begribes i denne sammenhæng, kan man heller ikke simpelthen gå ud fra den borgerlige stats mulige krisemanagement, fordi den krise, der skal »reguleres« kun er en umiddelbar fremtrædelsesform, der trænger sig frem, for de modsigelser, der stadig skærpes. Som følge heraf ville det ikke være krisen, som staten skulle manipulere med, men de modsigelser i den kapitalistiske produktion, som driver den frem. Men man kan med rette tvivle på, om staten som en institution på det bestående samfunds grundlag, - udstyret med funktioner, som selv er et resultat af modsigelser, der er kommet til udbrud - overhovedet er $i$ stand til at gøre noget ved disse modsigelser. Og videre: staten er selv fanget ind af samfundets modsigelser, hvilket allerede er vist*; hvordan skulle den så kunne regulere dem med effekt ${ }^{45}$ Af det kapitalistiske samfund og dets stats form følger derfor, at den principielt er ude af stand til at regulere de samfundsmæssige modsigelser. Men når staten så fungerer som krisemanager, griber den fat i fremtrædelses-

44. Theorien über den Mehrwert, MEW 26.2, s. 508-511.

* se tidligere s. 26-35.

45. Sml. fremstillingen af de statslige indgrebs modsigelsesfulde karakter hos E. Varga: Die Krise des Kapitalismus und ihre politischen Folgen, Frankfurt 1969, især s. 105 ff og 279 ff. 
formerne, symptomerne på de samfundsmæssige modsigelser, kriserne. Kun det borgerlige samfunds overfladebevægelser er tilgængelige for statens intervention, ikke de lovmæssigheder, som ligger til grund for dem. Enhver statslig handlen, som skal ophæve eller formindske konflikter, skaber derfor nye konflikter. Det er naturligvis umuligt at behandle alle de kapitalistiske krisers fremtrædelsesformer i dag, de statslige interventioner og deres resultater. Vi vil derfor begrænse os til et enkelt aspekt, som beskrives med det for nyligt fremkomne begreb »stagflation«. Vi vælger dette problem, fordi man her så smukt kan vise, hvorledes staten som »krisemanager « ikke blot svigter fuldkommen, men producerer stagflation som krisens specifikke fremtradelsesform, idet den ivarksatter den keynesianske krisemanagement på den kapitalistiske produktionsmådes grundlag, indfanget i dens modsigelser.

\section{2 "Keynesiansk"statsfunktion og stagflation}

I den »klassiske« konjunkturcyklus steg priserne i opgangsperioder, mens de faldt i nedgangsperioder. Det specifikke for den nyere tid er, at priserne $i k k e$ falder i recessionen, altså i nedgangsperioden. ${ }^{46}$ Dette udtrykkes i begrebet stagflation.

Lad os først se på prisbevægelsen. Vi skal ikke her vise udførligt, at hverken fagforeninger, »løn-prisspiralen « eller samfundets monopolisering er skyld i inflationen; debatten om denne tese føres i andre artikler. ${ }^{47}$ De sidste 20 års prisstigninger under den almene opgang på det kapitalistiske verdensmarked - en opgang, som kun har været afbrudt kortvarigt af svage recessioner - har langt snarere deres årsager i følgende: dels i kapitalens hurtige ekspansion, hvilket har forårsaget en udvidelse af kreditten i alle verdensmarkedslandene; dels i de ekstraprofitter, som de udviklede kapitaler kunne opnå i opgangen (hvad enten det drejer sig om enkeltkapitaler indenfor en nation eller om nationale totalkapitaler på verdensmarkedet), hvor jo ekstraprofitterne udtrykkes i, at prissænkninger ikke modsvarende følger stigningen i produktivkraften, og derfor altid indeholder et moment af »relativ inflation «, som Hoffmann kalder det; ${ }^{48}$ dels har prisstigningerne deres årsag i den disproportionalitet, der i opgangene er et resultat af produktionsprocessens stoflige betingelser, hvor denne disproportionalitet opstår som en følge af længden af bestemte varers produktionstid, mens råstoffer må købes og arbejdskraft betales til produktionen af disse varer. Herved udgår varer af markedet, uden at der leveres varer, mens penge på den anden side kommer i cirkulation. Endelig har prisstigningerne deres årsag i den

46. G. Bombach: Trend, Zyklus und Entwicklung des Preisniveaus, $i$ : Weltwirtschaftsarchiv 1970, s. 274.

47. Især Semmler/Hoffmann: Kapitalakkumulation, Staatseingriffe und Lohnbewegung, $i$ : Probleme des Klassenkampfs 2/1972. C. Neusüss: Imperialismustheorie und Weltmarktbewegung des Kapitals, Erlangen 1972.

48. Begrebet »relativ inflation« anvender Hoffmann til at karakterisere en proces, hvori "prisniveauet ... ikke følger den langfristede produktivitetsforøgelse - uanset om priserne stiger eller ej.« Hoffmann: Die säkulare Inflation, Berlin 1962, s. 10. 
kontinuerligt voksende statsgæld i de vigtigste kapitalistiske nationer, hvorfor de nævnte faktorer ikke ubetinget behøver at have deres oprindelse i hver enkelt nation for alligevel at øve indflydelse på den nationale prisinflationsproces. Så længe verdensmarkedet ekspanderer vil en nationalt begranset stagnation eller recession heller ikke føre til kompenserende prisfald, så længe der føres en »disciplineret « økonomisk politik, for så vidt som det pågældende land er integreret i verdensmarkedssammenhængen - og hvilken udviklet, kapitalistisk nation er ikke det i dag? Hvad man højest kan vente, er en periodevis prisstabilitet, som f.eks. i Tyskland efter 1966. Grænserne for den effektfulde nationalstatslige økonomiske politik ligger jo netop i verdensmarkedssammenhængen.$^{49}[\ldots]$.

Stagnation er krisens sarlige historiske fremtradelsesform, hvor krisen ikke efterfølges af en ny konjunkturopgang. Stagnationen udtrykker således en økonomisk tilstand, der er kendetegnet ved, at krisens »rensende« funktion endnu ikke er færdigudviklet. Ser vi det simplificeret, d.v.s. ud fra resultatet, har krisen først »renset« situationen, når enkeltkapitalernes profitrate igen er begyndt at stige efter det fald, der førte til krisen. Der må altså være kræfter i funktion i krisen, som på den ene side formindsker den kapital, som kapitalisterne skal indskyde f.eks. gennem et fald i prisen på den konstante kapitals elementer (råstoffer, maskiner) eller gennem et fald i den indskudte variable kapital (reallønfald, indskrænkning i antallet af beskæftigede arbejdere), og på den anden side øger udbytningsraten, frem for alt gennem en intensivering af arbejdet, en forlængelse af de beskæftigedes arbejdsdag. Med andre ord: for at en ny opgang skal være mulig, må kapitalen vardimindskes (»entwertung«) og den ikkeværdimindskede indskudte kapital må afkaste en højere profitrate og i sidste instans en højere merværdirate. ${ }^{50}$ Desuden må et rentefald og en formindskelse af jordrenten finde sted for at muliggøre en stigning i den industrielle profit; thi konjunkturen er afhængig af den industrielle profit, ikke af den rentebærende kapital. Og endelig må der opstå realiseringsmuligheder for en afsætning af de nyproducerede værdier, f.eks. gennem en åbning af nye afsætningsområder på verdensmarkedet. Hvis disse betingelser ikke - eller kun delvis - er opfyldt, så

49. Sml. Neusüss/Blanke/Altvater, op. cit. H. Arndt skriver: »Den, som i den vestlige verden i dag griber til en national beskæftigelsespolitik lige som i verdenskrisens tid, glemmer, at en national 'Deficit Spending' ikke kan have samme virkning i en verdensøkonomi som i en økonomi, der er mere eller mindre lukket gennem valutaregulering«; i: Stagflation, Was man bisher nicht wusste, Wirtschaftswoche nr. 1/1972, s. 20.

50. Her ser vi kernen i teorien om »overakkumulation - værdimindskning«, som den især fremføres af Boccara. For ham drejer det sig ganske vist mindre om en konjunkturel fremtrædelsesform end om en strukturel løsning på stagnationsproblemet i den statsmonopolkapitalistiske kapitalisme. Man må for så vidt være enig med ham, idet den borgerlige stat rent faktisk er i stand til at værdimindske kapital og dermed forsinke profitratens tendens til fald. For det første glemmes det for ofte, at denne værdimindskning selv er forbundet med konflikter, da værdimindskningen jo kun betyder udelukkelse af en kapital, som i sig kan udlægges produktivt (og hvilken enkeltkapitalist vil finde sig i dette helt uden konflikt?); for det andet må værdimindskningen ses i totalsammenhæng med problematikken omkring det produktive arbejde; og for det tredje forsvinder værdimindskningsproblematikken på ingen måde i kapitalakkumulationens cykliske forløb. Problematikken omkring overakkumulation - værdimindskning - er altså mere kompleks, end Boccara hidtil har fremstillet den. 
er en ny opgang tvivlsom, og så hersker der højst en »ligevægt gennem underbeskæftigelse«, altså stagnation, som karakteriseres ved "manglende investeringsmuligheder « for de private kapitaler.

De manglende investeringsmuligheder kan naturligvis kun ses i relation til den private kapitalakkumulation. I afsnittet om de almene materielle produktionsbetingelser gik vi stadig ud fra, at den manglende kapitalvalorisering i bestemte produktionsprocesser kunne fastslås for bestemte historiske faser, idet disse produktionsprocesser ikke - eller kun vanskeligt - kunne subsumeres under kapitalen som enkeltkapital på grund af deres særlige betingelser, mens der i andre sfærer af det kapitalistiske samfund findes en valorisering, som er tilstrækkelig til en hurtig akkumulation. Staten træder ind så at sige af »strukturelle« grunde. Det forholder sig anderledes i stagnationstilfældet, som jo netop er karakteriseret af en mangende valorisering $i$ den private sektor. Statens funktion består her ikke i at fremstille almene produktionsbetingelser for at muliggøre den samfundsmassige arbejdsproces, som middel til de mange enkeltkapitalers valoriseringsproces. Den skal derimod medvirke ved frembringelsen af forhold, som ganske vist gør krisen overflødig, men som $i$ deres virkninger udøver krisens rensende evne. Staten træder her ind så at sige af »konjunkturelle« grunde. Her ser vi det punkt, hvor staten bliver relevant med sine statslige udgifter; den stagnerende kapitalakkumulation bliver modvirket af statsudgifterne. For Keynes var statsudgifternes art ligegyldig, i hvert fald så længe det drejer sig om multiplikatoreffekten m.h.t. indkomst og beskæftigelse.

Men hermed er vi nået dertil, hvor den Keynesianske økonomi i hvert fald ikke selv vil hen, nemlig »i Say's Law of Markets'-verden; alene regeringen er den deus ex machina, som sikrer effektiv efterspørgsel ... « ${ }^{51} \mathrm{Og}$ med hensyn til problemet med skabelsen af de almene produktionsbetingelser, har vi hermed et eksempel på, hvorledes staten rent faktisk får en funktion i overensstemmelse med den private kapitals valoriseringsbetingelser, altså at staten netop får den og ikke andre funktioner overdraget udfra produktionsbetingelsers natur. Hvad der er almene produktionsbetingelser retter sig netop efter, hvad der i en specifik historisk situation ikke kan overtages af kapitalen selv. Eller sagt på en anden måde: Når kapitalens valoriseringsbetingelser kun tillader, at en del af et lands arbejderbefolkning kan beskæftiges som produktive. d.v.s. kapitalproducerende arbejdere, så findes kun alternativerne »underbeskæftigelse« eller statens uproduktive, d.v.s. ikke-kapitalproducerende anvendelse af dem. At staten ikke køber arbejdskraft med kapital, i hvert fald ikke i større omfang, fremgår allerede af, at staten ikke kan træde ind i konkurrencen med andre kapitaler som kapitalist, fordi dette ville betyde en yderligere forværring af den fulde beskæftigelse gennem en forværring af de allerede utilstrækkelige valoriseringsbetingelser, som allerede vist. 
Men i og med at staten i denne forstand griber til forholdsregler, der skal afværge en almen stagnation i den kapitalistiske økonomi, får dens økonomiske aktiviteter bestemte og alt efter udgiftsart forskellige virkninger på kapitaludviklingen. Udgiftsarternes virkninger skal nu fremstilles kort.

1. Hvis statens udgifter kommer arbejderklassen til gode uden indskrænkninger i den private konsumtion (f.eks. forbedret sundhedsvæsen og uddannelsessystem), så forbedres arbejderklassens andel af værdiproduktet, hvilket sikkert vil resultere i en lavere merværdirate og i sidste ende også $i$ en lavere profitrate for kapitalen. Forholdsregler med denne effekt kan derfor ikke opfylde det mål at overvinde stagnationen ved at sætte gang i kapitalakkumulationen.

2. Hvis statsudgifterne anvendes til at foretage en omfordeling af profitterne inden for kapitalistklassen gennem subvention, så kan man kun se en positiv effekt på kapitalakkumulationen, hvis de subventionerede kapitaler akkumulerer de modtagne tilskud, mens de kapitaler, som subventionen er taget fra gennem skatterne, omvendt ville have ladet de modsvarende beløb ligge brak eller konsumeret dem - nok et meget urealistisk tilfælde.

3. Hvis statsudgifterne anvendes til offentlige opgaver, så må man afgøre, hvad der videre sker med de varer, staten køber, hvilken del af det nationale revenu - løn- eller profitindkomster - de hovedsagelig finansieres af, og hvilken af de to klasser, de hovedsagelig er til fordel for. Thi deres virkning afhænger netop af disse forhold. I denne sammenhæng skal man undersøge, i hvilken udstrækning statsudgifterne tilflyder vare producenterne som penge, uden at de statskøbte varer selv igen bliver til varekapital eller produktivkapital i de mange enkeltkapitalers cirkulationsproces. Sådanne varer falder dermed fuldkommen ud af kapitalcirkulationen; de er »slutprodukter «, der hører hjemme i konsumtionen, selv om det ikke er den individuelle konsumtion i arbejderklassens reproduktion.

I denne sidste kategori falder især rustnings- og militærudgifter, som er den foretrukne form for statsudgift til at overvinde en stagnations fase: rustningsopgaver og de tilsvarende ordrer på andre arter af »spildproduktion« muliggør realisering af den producerende kapitalværdi netop i de grene, der lider mest under stagnationen eller depressionen, nemlig de produktionsmiddelproducerende industrier (dette udsagn er naturligvis afhængigt af rustningsteknologien). Rustningsvarer forhøjer hverken arbejderklassens realløn - det betyder altså ikke en omfordeling af nyværdien til fordel for arbejderklassen - og de kan heller ikke træde ind i konkurrence med andre privatkapitaler som produktivkapital. Set ud fra totalkapitalen finansieres rustningsudgifterne af det statslige revenu, som staten får enten gennem skatter - og dermed i det mindste delvis tages fra 
merværdien - eller gennem lån; men statslån bliver også lånt af kapitalisterne på kapitalmarkedet til en bestemt rentesats. ${ }^{52}$ Hvis rustningsudgifterne "selvfinansieres « af kapitalen og kommer den til gode i form af ordrer, kan man kun slutte, at der foregår en statsligt formidlet omfordeling inden for kapitalistklassens merværdi. Omfordelingen sker fra den akkumulationsduelige del af merværdien og fra den del, der tjener til kapitalisternes individuelle konsumtion til den statsligt formidlede destruktivt anvendte del. For økonomiens opdeling i produktionsgrene betyder denne omfordeling en begunstigelse af rustningsindustriens akkumulation og en relativ forsinkelse af akkumulationen i de øvrige grene. Når den akkumulationsduelige del af merværdien beskæres på denne måde, bliver den permanent anvendt til at trække varer ud af markedet, pumpe penge ind i kapitalcirkulationen og betale lønninger til arbejdere og især til ikke-arbejdere (soldater). Her er det klart, at resultatet for det forste bliver en permanent oppustning af prisniveauet og for det andet - under antagelse af, at hver akkumulationsbølge forhøjer kapitalens organiske sammensætning - at en forsinkelse af akkumulationsniveauet også vil forsinke tendensen til vækst i kapitalens organiske sammensætning, hvorved profitratens tendens til fald følgelig også vil modvirkes. En vedvarende stigning i statsgælden er forbundet hermed, hvilket vi allerede har omtalt under behandlingen af de inflatoriske faktorer.

Staten kommer altså ind i billedet i stagnationen, men spørgsmålet er, om den også kan bekæmpe den vedvarende og nå frem til en situation med »ligevægt ved fuld beskæftigelse«? Hvis der var grunde til at antage, at det kunne lykkes for staten at overvinde stagnationen gennem sine interventioner, så måtte vi revidere vores tese fra første afsnit om, at staten fungerer på grundlag af kapitalforholdet og er involveret i dets modsigelser uden at kunne løse dem på det bestående samfunds grundlag. Det kan dog ikke lykkes for staten; eller i hvert fald kun delvist, hvilket enkelte betragtninger skal vise:

For det forste er udvidelsen af rustningsindustrien og lignende områder (rumfart osv.) selv den vigtigste faktor i statsgældens vækst. Denne statsgæld modsvares jo i den samfundsmæssige cirkulationsproces af en voksende pengemængde, hvilket tenderer til en oppustning af værdiernes pengeudtryk. Thi som følge af den statsligt frembragte efterspørgsel efter penge bliver det muligt for enkelte kapitalister at forhøje deres priser. Hvorfor skulle de ikke gøre det, når de får forbedrede realiseringschancer på markedet? Andre kapitalister, som ikke direkte er leverandører til staten, bliver inddraget i denne proces, således at resultatet bliver en snigende eller endda galoperende inflation. Det ville ganske vist være for simpelt alene at udlede rustningssektorens vækst af den økonomisk forståede stagnation; det militære område bliver frem for alt udvidet for at opretholde eller udvide områder for den eller de nationale ka- 
pitalers herredøme (eller for at udvide »de demokratiske frihedsrettigheders« område). Som Rosa Luxemburg siger: militarismen betinger imperialismen og imperialismen betinger militarismen. Det har således også altid været de store krige, der resulterede ikke blot i en galoperende inflation, men også i en total destruktion af pengevæsenet. Og igen i dag er det en krig, der har fremkaldt den verdensomspændende inflation, nemlig US-imperialismens aggression, især mod de indokinesiske folk.

For det andet kan stagnationstendenser i et højtudviklet kapitalistisk samfund slet ikke overvindes på denne måde. Thi de kapitaler, der ikke producerer for det marked, hvor kapitalernes indbyrdes bytning foregår, men for staten, er også formidlet af konkurrencen - dvs. tvunget til at fungere som kapitaler. De må altså akkumulere, og det vil sige, at de ikke blot må udvide deres merværdiproduktion, men også deres vareoutput. Men dermed forlanges af staten, at den skal købe stadigt mere af disse kapitaler, dvs. at den skal forøge statsgelden, hvorved rustningsindustrien tendentielt vil overtage hele økonomien. Staten står således overfor alternativerne enten at tillade denne overtagelse, altså at begunstige akkumulationen i rustningsindustrien og dermed i sidste instans trænge de øvrige enkeltkapitaler, der ikke tilhører rustningsindustrien, tilbage ${ }^{53}$ eller at stoppe overtagelsen og dermed henvise rustningsindustrien til stagnation på et bestemt tidspunkt i dens udvikling.

I denne konsekvens manifesterer statens særlige funktion i det kapitalistiske samfund sig, såfremt et stigende antal produktionsprocesser kun kan opretholdes i kraft af statsligt formidlede omfordelingsforholdsregler på grund af profitratens historiske tendens til fald. Ved sikringen af de almene materielle produktionsbetingelser (»infrastrukturen«) findes en mathedsgrad for den statslige aktivitet, der er givet ud fra arbejdsprocessens karakter. Denne mæthedsgrad behøver ganske vist ikke at opnås under forudsætning af en »offentlig fattigdom«, men som ligger i sagens natur, nøjagtig ligesom der er givet en mæthedsgrad for de individuelle eller de samfundsmæssige behov vedrørende den enkelte vare set som brugsværdi. Produktionen af varen og produktion og drift af produktionsbetingelser bliver overflødige ud over denne mæthedsgrad. For at sige det med Keynes' ord: "To pyramider, to messer for den døde er dobbelt så godt som én; men det er to jernbaner fra London til York ikke. $\aleph^{54}$ Det kan være, at der slet ikke findes en jernbaneforbindelse mellem »London« og »York «

53. Dette vil få omfattende konsekvenser for kapitalens reproduktion og dens samfundsmæssige produktionsbetingelser. Følgen ville nødvendigvis være inflatoriske processer med udelukkelse af hele kapitalfraktioner, forarmelse af arbejderklassen, destruktion af kapitalismens samfundsmæssige produktionsbetingelser, nedbrydning af de retsforhold, der regulerer kapitalforholdet osv.; helt bortset fra de sandsynlige krigeriske opgør. De her kun antydede resultater er altid en tendens i kapitalismen, som kun kan modarbejdes effektivt af kapitalfraktionerne i perioder med almen opgang for kapitalen. Se evt. fremstillingen af den vesttyske industris interesser i genoprustning hos G. Brandt: Rüstung und Wirtschaft in der Bundesrepublik; Witten und Berlin 1966.

54. J. M. Keynes: The General Theory of Employment, Intrest and Money, (reprint) London 1964, s. 131. 
som et udtryk for den almene mangel på infrastrukturelle anlæg; men kun én jernbaneforbindelse ville være godt, to forbindelser ville være for meget. Det forholder sig helt anderledes med de statslige funktioner, hvor det ikke drejer sig om at oprette betingelser for alle kapitalers arbejdsprocesser, men hvor det drejer sig om at sikre enkeltkapitalers valorisering gennem omfordeling af værdier. Her gennemfører staten netop ikke ikke-kapitalistiske produktionsprocesser som i infrastrukturen, men den stotter akkumulerende kapitaler med sine udgifter. Her findes ingen mathedsgranse, da kapitalens valoriseringsdrift er umattelig; staten støtter her et produktionsområde, hvis opretholdelse kun er mulig gennem permanent udvidelse. Såfremt statsudgifterne, hvad de sigter imod, bliver et moment i enkeltkapitalernes cirkulationsproces, må de tilsvarende ekspandere disse enkeltkapitalers akkumulationsproces. To pyramider, to dødsmesser er derfor faktisk bedre end én, og tre er bedre end to, osv. - bedre for de kapitaler, som akkumulerer i disse grene.

Først analysen af den »keynesianske« statsfunktions karakter gør det muligt teoretisk at udlede stagflationens nødvendighed af arten af krisemanagement, og dermed begrunde den historiske tendens til stagflation. For nu får vi følgende konsekvens: Når rustningsudgifterne (og de økonomisk modsvarende statsudgifter) øges permanent, er følgen ikke blot en høj inflationsrate, men også en strukturel forandring af økonomi og samfund med negative virkninger for kapitalforholdets reproduktionsbetingelser. Dette fremkommer især, fordi rustnings- og militærudgifterne må stige progressivt, hvis de virkelig skal opfylde kapitalernes akkumulationsnødvendighed. De kapitalistiske staters historie har allerede bekræftet gentagne gange, at en sådan stigning kun kan finde sin voldelige løsning i krige. Men også stagnation i eller en sænkning af rustningsudgifterne forhøjer statsgelden absolut med hver udgivet pengeenhed. De inflatoriske tendenser virker altså videre, selv med stagnerende eller endog faldende rustnings- og militærudgifter. Men stagnerende militcr- og rustningsudgifter - uanset på hvor højt et niveau de er - betyder stagnation $i$ realiseringsbetingelserne og dermed også stagnation $i$ produktionen for de kapitaler, der producerer i disse sektorer. Følgen er brakliggende kapital; tilbagegang i bestillinger hos de kapitaler, der producerer for en kapitaludvidelse (producenter af produktionsmidler); mangelfuld kapacitetsudnyttelse og stigende arbejdsløshed.

Statsinterventionismen i den keynesianske betydning må altså derfor mislykkes, fordi arten af statsudgifter ikke er ligegyldig for kapitalens udvikling - altså omvendt af den keynesianske antagelse. Hvis statsfunktionen består i at muliggøre de akkumulerende kapitalers valorisering og dermed også selve akkumulationen, så må statsudgifterne hverken komme arbejderklassen til gode eller resultere i skabelsen af konkurrenter til disse kapitaler. Statsudgifterne må altså koncentreres i et område, hvor de hverken manifesterer sig i produktivkapital eller i konsumtionsmidler for arbejderklassen. Rustningsudgifternes 
fortrinsstilling i kapitalismen har altså en dybere økonomisk betydning. De indeholder dog den modsigelige, at det statsligt formidlede rustnings- og militærområde har tendens til at overtage alle andre samfundsmæssige områder og alle andre enkeltkapitaler. Hvis rustnings- og militærudgifterne når denne grænse, kan konsekvensen kun være krig indtil destruktion af de kapitaler, som er trykket af profitraten, eller en sænkning, resp. stagnation i rustnings- og militærudgifterne. Sidstnævnte alternativ er nu stagnationens årsag: statsgælden vokser videre, så længe rustnings- og militærudgifter overhovedet forekommer, og dermed består også det inflatoriske tryk stadigt. Med stagnation i statsudgifternes vækstrate er de kapitaler, der så at sige lever af dem, fordømt til stagnation: stagflation.

Vi ser altså hvorledes den fornyede stagnation og krise allerede ligger i de keynesianske forsøg på at overvinde stagnationen. Statsudgifternes oprindelige impuls kan virke positivt på kapitalens realiseringsbetingelser og hjælpe produktionen igang. Dette er i særdeleshed tilfældet, når rustningsudgifterne følges af en krig, hvis konsekvens ikke blot er udslettelse af mennesker, men også ødelæggelse af kapital (»værdimindskning«) i form af fysisk og værdimæssig destruktion. Dermed muliggør den en ny begyndelse på akkumulation ved en højere profitrate for kapitalen (»rekonstruktionsperiode«). ${ }^{55}$ Så længe denne periode varer, er de modsigelser skjult, som ligger i den statslige krisebekæmpelsesstrategis form, - de "modstridende agentier « har ikke nået deres fulde udfoldelse. I en almen opgangsperiode for verdensmarkedet, såsom efter 2. verdenskrig, kan stagflationer derfor ikke træde frem, eller kan kun gøre det i en hæmmet form. Rustningsudgifterne er ganske vist steget permanent i samtlige kapitalistiske stater - omend med en indbyrdes tidsforskydning: Vesttyskland udvikler først sin rustningsindustri fra 50'ernes slutning og Japan langt senere men samtidig var kapitalens valoriseringsbetingelser så gode, at denne statsaktivitet, som allerede nævnt, var gået relativt tilbage per saldo. Denne kendsgerning viser, at kapitalens akkumulation $i$ de sidste 20 år $i$ det vasentlige er et resultat af kapitalens egne iboende krafter. Men så snart fasen med hurtig akkumulation går mod sin slutning og profitraten virkeligt falder p.g.a. kapitalens stigende organiske sammensætning, vil den her nævnte modsigelse blive virksom. Den bliver fremtrædelsesformen i hele den kapitalistiske verden, formidlet gennem de nationale totalkapitalers verdensmarkedssammenhæng, medens dens udtryksform i form af stagflation indtil da har været nationalt begrænset (USA 1958).

Det, som i dag betegnes med det nye begreb stagflation, er altså ikke noget nyt, men blot en benævnelse for den fundamentale modsigelse, som ligger til

55. Rekonstruktionsperiode betegner opgangsperioden umiddelbart efter de to store verdenskrige, som var kendetegnet af en meget hurtig kapitalakkumulation og udvidelse af produktionen - jvf. det tyske økonomiske »mirakel«, det sk. »Wirtschaftswunder«, samt den hastige udvikling i Japan. Se Janossy: Das Ende der Wirtschaftswunder, Frankfurt 1969. 
grund for den keynesianske strategi til undgåelse af kriser, og som fremtræder historisk og synligt tilspidset ved udgangen af en langvarig opgangsperiode for verdensmarkedet.

\section{Betydningen af "videnskaben " om statsinterventionismen}

På trods af de her viste modsigelser, som den borgerlige stat er indfanget i, tilbyder den borgerlige videnskab at levere modeller og materialer til staten, hvormed den skulle kunne gennemføre interventionerne mere effektivt i økonomien. I modsætning til den klassiske politiske økonomi, hvis erkendelsesmål faktisk var analysen af det borgerlige samfunds anatomi, er den nutidige samfundsvidenskab i vid udstrækning rettet mod spørgsmålet: hvad skal politikerne stille op med resultaterne, når de får dem i hænde? Denne videnskab begrænser sig selv til i sine analyser og forskningsprogrammer til de områder, som virkeligt står til disposition, d.v.s. til kapitalforholdets overfladefremtræedelser, fordi den indretter sig på en politiker-forståelse, hvori kun begrebet: manipulation med samfundsmassige processer fra statens side, formår at udtrykke forholdet mellem stat og økonomi adækvat. Begrebet om samfundsmæssig modsigelse må herved gå delvis eller helt tabt, og dermed også evnen til at erkende samfundsmæssige modsigelser; til nød ser man nok konflikter, som det netop gælder om at manipulere med, men derudover undgår man i stadig større omfang at analysere krav til, betingelser, forudsætninger og muligheder for samfundsmæssige forandringer. Ligesom videnskabelig fremskridt betragtes udfra en trinsvis indsamling af yderligere fakta, således ses også udviklingen af statens evne til manipulation udfra en trinsvis vækst i de data og processer, som af videnskaben erkendes som manipulerbare. På grund af denne forståelse kan videnskabelige charlataner stadigvæk komme til ære, værdighed og indflydelse i samme udstrækning som de blot opdager nye "manipulerbare data og processer ${ }^{56}{ }^{56}$ Den ægte pessimistiske indstilling hos mange af de videnskabsmænd, som orienterer sig mod rådgivning, skyldes ikke mindst den erfaring, at politikerne på trods af alle rådgivende forslag må handle ud fra deres politiske ansvarlighed, deres intuition, deres praktiske forståelse uafhængigt af og under visse omstændigheder også direkte imod rådgiverne; vendt teoretisk om fører denne erfaring lige over i en accept af påstanden om, at politik og videnskab er to forskellige områder, underlagt forskellige regler og udfyldt af mennesker af kontrær naturbeskaffenhed. Flugten ind i denne type dikotomi er kun bagsiden af samhørigheden mellem økonomi og politik, hvilket vi nu skal vise.

56. Et typisk eksempel er den såkaldte Chicagoskole inden for pengeteorien, hvis hovedrepræsentant, Milton Friedman, steg helt op i den amerikanske præsidents rådgivergruppe - for her blot at vise sin fuldstændige uduelighed. 
For at se hvorledes en videnskab, som er orienteret mod politiker-rådgivning, går til værks, skal vi først se på et eksempel, før vi drager vores slutninger. Man kan principielt sige, at en søgen efter yderligere informationer er trådt i stedet for en erkendelsesinteresse for teoretisk indsigt i samfundsmæssige processer. Det forventes, at man kan skabe nye og komplicerede forløbsanalyser af disse informationer. Denne problemstilling gennemsyrer netop de betænkninger, hvoraf politikken fremstilles med en aura af videnskabelighed og klasseneutralitet, og derfor vil vi undersøge problemet gennem en analyse af det økonomiske råds årsberetning om den samfundsøkonomiske udvikling. ${ }^{57}$

Årsberetningerne er affattet helt i overensstemmelse med deres pålæg, sådan som det er formuleret i loven om oprettelsen af et økonomisk råd. Denne lov pålægger Rådet at "give en fremstilling af den givne samfundsøkonomiske tilstand og dens fremtidige udvikling « og at undersøge »hvorledes en samtidig stabilitet i prisniveau, høj beskæftigelsesgrad og ligevægt i udenrigsøkonomien kan garanteres inden for den markedsøkonomiske ordens rammer ved en stadig og passende vækst.« Selve loven forbindes altså med den økonomiske udviklings fremtrædelsesformer, hvoraf enkelte fremtrædende indikatorer, nemlig prisniveau, beskæftigelsesgrad, udenrigsøkonomisk ligevægt og økonomisk vækst defineres som politiske kriterier for en samfundsøkonomisk ligevægt inden for en markedsøkonomisk orden. Disse fire politiske kriterier på en samfundsøkonomisk ligevægtstilstand er som bekendt indbyrdes modstridende (den sk. magiske firkant). Den borgerlige økonomi og den økonomiske politik har siden hen opgivet at opfylde alle fire mål samtidig, og her kommer det indirekte til udtryk, at den borgerlige økonomi ikke er i stand til at abstrahere fra de kapitalistiske modsigelser i det øjeblik, hoor den skal vare praktisk. Deraf slutter Det økonomiske Råd, »at Det økonomiske Råd altid må rette den største opmærksomhed mod de mål, som er mindst virkeliggjort i den givne samfundsøkonomiske situation og dens fremtidige udvikling." (JG 67/68 Vorwort, Ziff. 3). Hvor indbyrdes modstridende målene er, afhænger naturligvis af selve konjunkturudviklingen. Denne vurdering når Det økonomiske Råd også til gennem empirisk observation, som det har gennemført i betænkningen i 69/70. Det undersøger (Ziff. 231) »i hvilken udstrækning den samfundsøkonomiske udvikling har afveget fra disse fire store mål i de sidste 6 år « og kommer til dette resultat: »Nærmest målene kom man i opgangsåret 1964, hvor kun pengeværdistabiliteten ikke blev opfyldt; næstnærmest i opgangsåret 1968, hvor forholdene var nogenlunde de samme, bortset fra at den udenrigsøkonomiske ligevægt var stærkt forstyrret. Disse observationer synes at bekræfte den opfattelse, at de store mål for den økonomiske

57. Der menes betænkningerne fra det tyske »Sachverständigungsrat« - en institution, som i Danmark modsvares af det økonomiske råds formandsskab, de såkaldte »vismænd«. I det følgende kaldes »Sachverständigungsrat« for Det økonomiske Råds. Litteraturhenvisningen JG står for »Jahresgutachten«, altså den årlige oversigt. 
politik kun forbigående vil kunne virkeliggøres samtidig - i de perioder med økonomisk stigning, som følger efter faser med utilstrækkelig kapacitetsudnyttelse.«(JG 69/70 Ziff. 231). På det empiriske område fremtræder her altså den kendsgerning, at en totaløkonomisk ligevagt inden for en kapitalistisk økonomi $i$ hvert fald kan eksistere $i$ depressionsfasen efter, at krisen har udøvet sin 'rensende' kraft. Man må for så vidt modificere denne generelle konstatering, eftersom der ikke herskede en langvarig depression efter krisen i 1966/67 netop på grund af den »udenrigsøkonomiske uligevægt«, dvs. det usædvanligt store overskud på den vesttyske handelsbalance. Men tendenserne til en forbigående ligevægt som følge af krisen har også vist sig efter 1966/67, hvor både en kapitalværdimindskning (bankerotter, koncentration gennem tilintetgørelse af små og mellemstore kapitaler, afskrivning af lagre og forældede anlæg osv.) og en arbejdsintensivering fandt sted, dvs. at både den indsatte kapital blev forringet relativt i forhold til profitmassen og at merværdiraten blev forøget. Den af Det økonomiske Råd konstaterede modsigelse i virkeliggørelsen af målene er kun den øverste overflade af den kapitalistiske akkumulationsbevægelse, og med denne som vurderingsgrundlag for de 4 politiske kriterier kan disses sammenhæng helt bestemt ikke analyseres. I sin rodfæstelse i akkumulationsprocessens fremtrædelsesmåder kan Det økonomiske Råd påberåbe sig den lov, som netop påbyder dette. Det økonomiske Råd accepterer dette påbud og afstår dermed fra analysen af de grundlæggende modsigelser, der burde påvises som årsag til alle de 4 måls udvikling. Således forbliver den indre sammenhæng i det, som Det økonomiske Råd skulle analysere, nemlig krisecyklen, skjult for Rådet.

Her må vi naturligvis fortsætte med spørgsmålet, om det kun har været lovgivernes manglende teoretiske indsigt, som har foreskrevet denne rodfæstelse i overfladefremtoningerne, eller om der ligger andre grunde bag. En forudsætning for muligheden for manipulation med reale økonomiske kategorier (økonomisk politik) er en vis eklekticisme i teorien. ${ }^{58}$ Først herved bliver den forudsætning skabt om, at de faktorer, som manipulationen skal omfatte, kan betragtes og behandles som isolerede. Når lovpåbudet er formuleret ud fra nødvendigheden af en borgerlig økonomisk politik, kan man følgelig heller ikke vente andet af denne opgave end den nævnte isolering af faktorer, end en afvejning af gensidigt isolerbare politiske kriterier i det borgerlige samfunds overflade. Vi indser, hvorledes den borgerlige økonomiske teoris udvikling til

58. Det siger noget om dagens virkelighed, at netop den borgerlige konjunkturteoris eklekticisme ses som et fremskridt: "Man kan i almenhed sige, at konjunkturlæren altid er blevet mere eklekticistisk. Derved er den blevet mere elastisk og mere ydedygtig med hensyn til de stillede opgaver . . «W. Weber og Hubert Neiss: Entwicklung und Probleme der konjunkturtheorie, Köln-Berlin 1967, s. 18. I eklekticismen opløser konjunkturteorien endegyldigt sammenhængen mellem konjunktursvingninger og kapitalforhold, fordi der ikke længere kan være tale om en samfundsmæssig totalitet. Den atomiserer langt snarere denne totalitet. Netop herved bliver den mere "ydedygtig med hensyn til de stillede opgaver«, dvs. anvendelig til teoretisk reflektion af politisk manipulerbare enkeltfaktorer med henblik på at undgå kriser. 
eklekticisme modsvarer den økonomiske politiks krav til den økonomiske teori, hvilket bestyrker rodfæstelsen i overfladefremtrædelserne.

Man må se på endnu en betragtning over Det økonomiske Råds opgave. Det drejer sig om den borgerligt-positivistiske adskillelse mellem rådgivning og politik, som udtrykkes i forbudet mod anbefalinger: "Med den i loven nedlagte begrænsning i opgaven . . . som består i, at Det økonomiske Råd 'ikke skal udtale anbefalinger af bestemte økonomiske og socialpolitiske forholdsregler' har lovgiverne umisforståeligt udtrykt, at den politiske ansvarlighed på dette område udelukkende ligger hos de forfatningsmæssigt kompetente organer; de ønsker ikke engang anbefalinger, som vil kunne svække denne ansvarlighed udadtil.«(JG 67/68 Vorwort Ziff. 5). Grundlaget for denne selvbegrænsning kan kun ligge i, at det anerkendes, at det er umuligt at udsige rigtige domme i det borgerlige samfund. Den borgerlige teoretiker er ikke altid i stand til at erkende, hvad der er rigtigt og sandt. Men da staten i stadig større omfang må gribe regulerende ind i økonomien - da man altså ikke længere kan lade sandhedsproblemet hvile i »laisser faire, laisser aller « $\mathrm{i}$ tillid til, at det borgerlige individ formår at handle autonomt og rationelt ud fra sine egne interesser - er kun decisionismen tilbage, som forsikrer $\mathrm{om}$, at en politik selv kan være eller kan blive rationel, når den er forsynet med gode informationer. Således må politikerne træffe beslutningerne og her må de kunne sætte sig ud over den videnskabelige sagkundskabs betænkninger: »Videnskaben må heller ikke drive det så vidt på dette område, at den politiske praksis fratages enhver risiko. ${ }^{59}$ Adskillelsen mellem videnskabelig rådgivning og politik har således sin årsag i det borgerlige samfunds modsigelser, i de forskellige klassers forskellige kontrære og antagonistiske interesser. Disse modsigelser fremstår i fremtrædelsernes overflade som politiske målkonflikter. I det borgerlige samfund kan den videnskabelige sagkundskab kun levere bidrag og forslag til deres løsning. Politikken bliver i sidste instans overladt til voluntarisme og decisionisme.

Men hertil kommer der endnu noget andet. Det, at der overhovedet er blevet dannet et råd af sagkyndige til bedømmelsen af hele den økonomiske udvikling, skyldes den antagelse, at man vil kunne øge den økonomiske politiks rationalitet gennem forbedret information om mål, målkonflikter, mål-middelkonflikter, om funktioner og forløb inden for det givne system. For Dürr tager det sig ud på følgende måde: "Inden for konjunkturpolitikkens område er hovedformålet formindskelsen af konjunktursvingningerne. Hvis en teori angiver konjunktursvingningernes uafhængige variable (årsager), kan man nå målet 'stabilisering af den økonomiske udvikling' gennem den direkte eller indirekte ændring af disse uafhængige variable. Når konjunktursvingningernes årsager ikke afdækkes af konjunkturteorien eller når konjunkturteoriens konjunkturpolitiske følgeslutninger ikke lader sig gennemføre, kan man forsøge at lade de konjunktursymptomer, 
som opfattes som uønskede, ude af betragtning. Sådanne symptomer er specielt prisstigninger, som for det meste er forbundet med højkonjunkturen, samt arbejdsløsheden under depressionen. På den anden side anvendes der til fjernelsen af disse konjunkturmæssige følgefremtrædelser teorier, som indeholder prisniveauet henholdsvis beskæftigelsen som afhængig variabel, og som angiver de uafhængige variable, der kan være udgangspunkt for den symptombekæmpende konjunkturpolitik. Hvis prissvingningerne var årsagen til konjunkturerne, så ville prisstabiliseringspolitikken være en årsagsbekæmpende konjunkturpolitik. Dette synspunkt blev forsvaret i 1920'erne. Men i mellemtiden har det vist sig, at prisniveauets stabilitet under højkonjunkturen ikke pålideligt kan forhindre krisen. I USA kunne man i 1920'erne endog iagttage en mindre prisnedgang, og alligevel udbrød der i 1929 den hidtil alvorligste økonomiske krise..$^{60}$ Man kan altså kun antage, at informationer om faktorernes bevægelse og supplerende antagelser om deres afhængighed forøger muligheden for reguleringen af disse faktorer, hvis de enkelte momenter i kapitalens bevægelser, som hænger sammen og formidles modsigelsesfuld, kan begribes som simple faktorer, som årsager, som uafhængige variable. Reguleringsmuligheden kræver allerede elimineringen af modsigelserne, kræver konstruktionen af et »system《, som kan bringes til at fungere bedre. Rationalitet i betydningen garantien for de »fire mål« kræver altså til enhver tid netop de af målene, som skaffer sig den største opmærksomhed, og som i hele den nuværende økonomiske situation og dens overskuelige udvikling er mindst virkeliggjort. Dette kan kun betyde: isolering af virkningen på andre mål. Da der er forbundet konkrete interesser med de nuværende mål, må dette også betyde: undertrykkelse af konkrete interesser til gunst for helhedens »rationalisering". Dette lader sig ikke hindre i det borgerlige klassesamfund, som kun fremstiller helhedens rationalitet som en fiktion, der til stadighed bryder med de enkelte klassers rationalitet. Arbejderklassens rationalitet og kapitalens rationalitet er antagonistiske. Benægtelsen af rationalitetens antagonistiske karakter fører direkte til enten naive eller kyniske råd om forbedringen af den økonomiske politiks »rationalitet«. Også derfor er Det økonomiske Råd et godt eksempel, som det nu skal vises.

I $\sin 4$. årlige betænkning, altså efter erfaringerne fra den økonomiske krise 1966/67 (som Rådet end ikke én gang mente at kunne se i anmarch, jvf. Ziff. 233), giver Det økonomiske Råd et tilbageblik for at reflektere over, »hvordan man kan fjerne og fremtidigt undgå eksisterende uheldige udviklinger «. (Ziff. 219). Som uheldige udviklinger defineres afvigelser i et bestemt kvantitativt omfang fra de nævnte mål. Principielt går det økonomiske råd ud fra, at det er muligt at undgå uheldige udviklinger, og det for det forste gennem en tidlig erkendelse af uheldige udviklinger og for det andet gennem en større henholdenhed og stabilitet i den økonomiske politik: »Skal væksten - med stabilt prisniveau - være vedvarende, sådan 
som den var det tidligere, må man endnu mere indstille konjunkturpolitikken på kortfristede mål. Frem for alt kommer det an på, at man rettidigt erkender uheldige udviklinger og forebyggende modvirker dem i stedet for at korrigere dem bagud med den risiko, at der derved sker for meget med varerne og cyklus'sen derigennem forstærkes. Med tiden må kortfristede mål og en konjunkturpolitisk henholdenhed, som er ligeså fjernt fra den skødesløse 'laisser-faire' som fra den hvileløshed, som redningsmand er tvunget til under krisen, egentlig også i investorernes kreds fremkalde tillid til en stabil og stadig udvikling og derigennem bidrage til, at den private investeringslyst fremtidigt svinger mindre end tidligere. I den økonomiske politik er et tidsperspektiv på flere år forsåvidt en nødvendig betingelse for en stadig vækst; fremfor alt i en markedsøkonomisk ordning, hvor der gives mange arbejdsgivere, som selv bærer risici'erne og udnytter chancerne ved den private ejendomsret til produktionsmidlerne.«(JG, 1967, Ziff. 220).

I dette citat antydes den implicitte teoretiske forestilling om konjunkturudviklingen. Det er tilliden hos investorerne, som formår at forhindre de uheldige udviklinger, d.v.s. de økonomiske kriser; altså den samme psykologisme, som er vidt udbredt i den nuværende vulgør-økonomi. ${ }^{61}$ Selv om Det økonomiske Råd jonglerer med righoldig økonomiske materiale, selv om det anvender tilfilede statistiske metoder til bearbejdelsen og fortolkningen af dette materiale, er dets konjunkturpolitiske forestillinger, og det overrasker ikke, ikke økonomisk, men psykologisk begrundet. Det økonomiske Råds slutbemærkning må da også lyde: uheldige udviklinger er konsekvensen af mistillid hos investorerne.$^{62}$

Men man må så stille spørgsmålet: hvad er da årsagen til denne mistillid hos investorerne, eksempelvis til den mistillid, som i 1966 førte til den økonomiske krise. (Vi forsøger med dette spørgsmål at rekonstruere Det økonomiske Råd konjunkturtteori, som det jo intet steds har forklaret). Som årsag til krisen 1966/67 anfører Det økonomiske Råd følgende faktorer: »Tilbagegangen i den private og offentlige investeringsefterspørgsel har indledt indskrænkningsprocessen.« (JG, 1967, Ziff. 3). »En tiltagende restriktiv penge- og kreditpolitik har skærpet investeringsefterspørgslens cykliske tilbagegang.« (JG, 1967 Ziff. 4). »Stigende lønninger og priser foranledigede allerede i maj 1966 Forbundsbanken til at stadfæste sin restriktive kurs.« (Ziff. 4). „Den uheldige udvikling er imødegået for sent og tøvende af de økonomisk-politiske instanser.« (Ziff 6).

61. Jvf. eventuelt W. A. Jöhr, Alternativen der konjunkturklärung, i Wilhelm Weber (udg.), i omtalte bog, s. 353 ff, som betjener sig af den mest smagløse massepsykologi for at »forklare« konjunkturprocesserne. Også Keynes' centrale kategorier er psykologiske: hang til forbrug, investeringslyst, forkærlighed for likviditet, osv.

62. Hos Günther Schmölders, Konjunkturen und Krisen, Reinbeck 1955, s. 112, hedder den tilsvarende økonomiske politiks konsekvens: „Følgelig må også konjunkturpolitikken til enhver tid udvikle den til den givne situation bedst tilpassede fremgangsmåde, således som den allerede er blevet anvendt i de forskellige lande med større eller mindre resultat; alle erfaringer tyder på, at derved får både den offentlige menings indflydelse, den 'moralske overtalelse' gennem rettidige advarsler og påmindelser, såvel som 'signalvirkningen' af diskonto-forholdsregler og lignende, særlig betydning.» 
». . var den nationale og lokale finanspolitik dengang endnu helt og holdent indrettet på at bringe budgettet i orden gennem udgiftsnedskæringer og stigning i skatteudskrivningerne, uden hensyn til hvad der var konjunkturpolitisk påkrævet.« (Ziff. 7). Vi ser altså, at Det økonomiske Råd næsten udelukkende anfører økonomisk-politiske fejltagelser som årsag for recessionen i den første årsberetning efter den økonomiske krise. Fejltagelser $i$ den økonomiske politik er efter det økonomiske råds forestillinger ansvarlige for »uheldige udviklinger« $i$ økonomien. Dette bliver endnu tydeligere, nær vi betragter de »sidste 6 års konjunkturpolitiske lære«, som Det økonomiske Råd forsøger at uddrage i årsberetningen fra 1969 (Ziff. 232). »Til de grunde, som kunne forklare, at alle økonomiske mål så sjældent blev nået samtidig, hører visselig også omstændigheder indenfor konjunkturpolitikkens område. Det kan have spillet en rolle, at der ... findes forsinkelser og undertiden blokeringer; at vigtige forholdsregler derfor udebliver ...; at de uafhængige gruppers adfærd ofte ikke eller kun utilstrækkeligt var koordineret med de statslige instansers målforestillinger ...«. Hvad skal man mene om en sådan forklaring? Enten gøres symptomer til årsager (tilbagegang i den private og offentlige investeringsefterspørgsel, restriktiv pengeog kreditpolitik) eller den økonomiske politiks fejltagelser fremstilles som kriseårsag.

Ganske vist er der også system i analysens overfladiskhed. For når investoren opfattes som konjunktur-udviklingens bevægende årsag (ligesom den »dynamiske arbejdsgiver « hos Schumpeter), så må det naturligvis undersøges, hvilke faktorer der netop bestemmer denne tillid hos investoren. "Investoren«, læs: kapitalisten, kan jo alligevel kun orientere sig mod symptomer. Da nu symptomerne ifølge den borgerlige økonomiske teoris grundlæggende antagelse kan formuleres "politisk «, er krisens årsag i sidste ende den økonomiske politiks svigten (JG, 1969, Ziff. 239). Der uddrages af denne begrundelse for krisen mistillid hos investorerne - nu den omvendte slutning: Den situation, som investorerne vil kunne have tillid til, lader sig etablere gennem den økonomiske politik. Og her får Det økonomiske Råd en god ide: For det første må den uheldige udvikling modvirkes forebyggende med den rigtige »timing « og ikke først, når den allerede er skudt helt i vejret (JG, 1969, Zff. 263). »Skal de store mål i den økonomiske politik virkeliggøres bedre i fremtiden end i de forgangne seks år, så kommer det frem for alt an på, at man griber til konjunkturdæmpende forholdsregler, før opsvinget når sit højdepunkt, og at man indleder en efterspørgselsekspanderende politik, før økonomien har nået bunden. For modvirker man ikke forebyggende de uheldige udviklinger, så består, som påvist, den fare, at det rigtigt sker for sent og derigennem bliver forkert. I første tilfælde forstærkes det næste tilbageslag, i det andet tilfælde fyres der op til det næste boom«.

For at kunne sætte ind med den økonomiske politik med rigtig »timing « må forskellige betingelser forbedres eller først genoprettes (Ziff. 264). Hertil hører en »forbedring af den konjunkturpolitiske beslutningsproces«, et »frit 
valg i kombination af midler, som tager hensyn til en åben økonomis særtræk«, den »indkomstpolitiske sikring af den økonomiske politiks program, - når man kan frygter en konjunkturpolitisk ekstrem situation, (JG, 1969, Ziff 264), og slutteligt overholdelse af bestemte forholdsregler for de 'uafhængige grupper'. Af det økonomiske Råds forklaring på sit konjunkturteoretiske grundlag kan man slutte sig til følgende grundantagelser i denne teori: det handlende individ indenfor økonomien, altså særligt 'investorerne', men også 'konsumenterne' bestemmer konjunkturforløbet gennem deres handlinger eller undladelser. Psykologiske kategorier som 'tillid' og 'mistillid' er for såvidt nødvendige kategorier indenfor denne konjunkturteoretiske position, også når de i højeste grad er vulgærøkonomiske. Det økonomiske Råd fortsætter således en tradition indenfor den borgerlige økonomi, indenfor hvilken det handlende menneske altid vil være "økonomiske subjekter" (rettere: tingsliggjorte menneskehylstre ligesom det 'økonomiske menneske'; hvorimod arbejderne kun har »subjektkarakter" som »konsumenter « i reproduktionsområdet; i produktionsområdet tæller de som tingslig "produktionsfaktor: arbejde«). Tillid og mistillid hos investorer og konsumenter fremspringer rigtignok ikke af deres psyke, men er afhængig af de økonomiske betingelser. Disse rammebetingelser karakteriseres gennem størrelser som: prisudvikling, ordretilførsel, omsætning, eksport-import-saldo, renteniveau, aktiekurser, lønniveau, gevinsternes størrelse, størrelsen af disponibel konsumentindkomst, o.s.v. De er altså bestemt gennem faktorer, som Det økonomiske Råd udførligt undersøger udviklingen af i det til en hver tid vurderede år. Disse enkelte størrelsers eller faktorers totalsammenhæng fremtræder kun som en række »syntetiske indicier «, så som industriproduktion, brutto- eller nettonationalprodukt og nyskabelser i konstruktionen af en totalindikator, som skal muliggøre tidligere erkendelse af konjunkturforløbet. ${ }^{63}$ Bedømmelsen af disse faktorers totalsammenhæng udfra synspunkter om alle de økonomiske forholds ligevægt og uligevægt formidles af de kvantitative afvejninger af de fire allerede nævnte mål for hele økonomien på grundlag af deres politisk fastsatte normværdi. Først på grundlag af disse faktorer og deres syntetisk formidlede udtryk fremkommer det, som sædvanligvis kaldes for det økonomiske system: et system af faktorer, som er uddraget af hinanden og som er indbyrdes afhængige. Sammenhobningen af faktorer, de økonomiske subjekters handlinger eller undladelser, bestemmer dette økonomiske systemt bevægelse.

Kapitalen - forstået som alle disse faktorers bevægende kraft, som »systemtvangen « bag alle disse »autonome subjekter «, der jo kun kan forstås rigtigt som kapitalforholdets karaktermaske - spiller ikke nogen rolle i denne analyse.

63. Disse totalindikatorer, som regelmæssigt bliver offentliggjort $\mathrm{i}$ »Wirtschaftswoche«, fungerer tydeligvis ikke i tider med stagnation og med stagflationens specifikke modsigelser. "Wirtschaftswoche« skriver således den 3. marts 1972: »Medens (totalindikatoren) relativt godt beskriver den forgangne konjunkturcyklus, er den i den nye, stagflatoriske situation ikke mere korrekt ...«(S. 59). 
$D a$ altså kapitalforholdet som kategori, der i første række skulle være reproduceret teoretisk udfra den samfundsmæssige totalitet, end ikke er blevet bevidst elimineret i Det økonomiske Råds vurderinger; $d a$ økonomisk analyse endnu kun betragtes som analyse af isolerede, modstridende fakta, data, faktorer; $d a$ den økonomiske beslutningsproces følgelig fremstilles på basis af »tillid« og »mistillid«; $d a$ hele den kapitalistiske økonomi er opløst i tidsrækker, små enheder, selvstændige subjekter (hvis enestående betydning i form af små og middelstore arbejdsgivere fremhæves på ethvert, kun nogenlunde passende sted af Det økonomiske Råd), så kan den totalsammenhang, som har påtvunget sig selv målkonflikter og cykliske bevagelser, rigtignok kun fremstilles af et hypersubjekt. Altså fremstilles af et subjekt, som har det største overblik over de mange data og faktorer, som i sine handlinger har et videre tidsperspektiv end de andre $ø$ konomiske subjekter, som på den anden side er i stand til at tage hensyn til de mange enkeltinteresser, der af det økonomiske råd kaldes for »totalinteressen « eller "almenvellet«, helt i den affirmative sprogordens tradition. Netop opløsningen af den samfundsmassige totalitet $i$ de mindste enheder resulterer logisk $i$ den hypostaserede betydning af statens økonomiske politik for reguleringen af helheden. Kun på grundlag af en sådan teoretisk vurdering er det muligt at søge årsagerne til den »uheldige udvikling « i statens økonomiske politik, og kun på dette grundlag er det også muligt at formulere forslag, advarsler, råd, »objektive nødvendigheder « for den statslige politik som »krise-undgåelses-strategier« uden videre omsvøb eller særlige, teoretiske skrupler.

Ser man endnu én gang på det økonomiske råds forslag til den økonomiske politik, så vil man se, at forslagene går ud på en videre hypostasering af statsapparatet, for såvidt de angår institutionelle ændringer: begrænsning af uafhængigheden hos de 'autonome grupper', forbundscentralisering af den økonomiske politik, altså ophævelse eller indskrænkelse i den føderalistiske struktur, begrænsning i »beslutningsprocessens rigiditet«, hvor den lovgivende magt overgiver flere konjunkturpolitiske beføjelser til den udøvende magt (JG, 1969, Ziff. 267), og mere af samme slags. Derved ændres der jo ikke grundlæggende ved kapitalforholdet og dets bevægelser - dette er et punkt, som hyppigt bedømmes fuldstændigt forkert, da mange venstre-kritikere mangler, om ikke ordet, så kapitalens begreb. I følge dette må hypostaseringen af staten for det forste selv udledes af den borgerlige økonomis særlige form; men for det andet kan den først rigtig udledes på grundlag af de objektive betingelser, under hvilke staten griber regulerende ind, hvad der straks skal vises.

Til en sådan fremgangsmåde, som er typisk for Det økonomiske Råd, er der naturligvis kun tilbage at sige: de bestandige forsøg på enten at vise krisens tilfældige karakter eller at eftervise årsagerne til krisen i subjektive fejltagelser, og ikke i de objektive økonomiske forhold, altså at benægte den nødvendige sammenhæng med den kapitalistiske økonomiske orden, har »deres årsag i den 
borgerlige videnskabs apologetiske bestræbelser på at vogte den bestående økonomiske orden mod enhver kritik. « ${ }^{64}$ Apologi er dog ikke nogen videnskab og dens prognoser kan følgelig også kun være tilfxeldigt rigtige, og derfor kommer Det økonomiske Råds analyser nu og da på tværs af den virkelige udvikling. Således i 1966, da den økonomiske krise indtrådte, hvad Det økonomiske Råd ikke var i stand til at forudsige, end ikke engang i en meget kortsigtet prog nose.$^{65}$ Det kan næppe være anderledes. Selv Det økonomiske Råd må opgive den terminologiske ensartethed og ensartetheden i den teoretiske analyse. I sammenhængen med recessionen fra 1966/67 taler Rådet uden blusel om »renselseskrise eller om »stabiliseringskrise«: »Den anden tese, recessionen har karakteren af renselseskrise og fordrer for så vidt en økonomisk vækst på længere sigt, gælder kun, hvis det i forvejen er blevet forsømt at undgå overdrivelser. Efter den økonomiske politiks fejltagelser og forsømmelser i 1964/65 har en mild recession i 1966/67 sikkert haft en rensende og dermed vakkstbefordrende funktion indenfor visse grænser ... Skal væksten være mere stabil end tidligere, så må man forsøge at bremse det fremtidige opsving rettidigt og blidt, for at der herefter ikke mere (!) behøves en renselseskrise ...«. (JG, 1967, Ziff. 239). I begrebene »renselseskrise«, »stabiliseringskrise«, »ligevægt gennem underbeskæftigelse« formuleres den resterende realisme inden for den borgerlige teori uden at det begribes, at der ikke står andet bag disse bevidstløst anvendte begreber end den kendsgerning, at økonomiens »ligevægt« indenfor kapitalismen til stadighed må frembringes voldeligt og periodevis gennem krisen.

Eksemplet med Det økonomiske Råd viser følgeligt to ting: for det forste medfører den kapitalistiske udviklings naturlighed og den statslige interventionsmuligheds begrænsning en form for videnskabelig rådgivning, som må baseres på helt overfladiske teorier. Det er denne videnskabs intention at levere bidrag til politisk rådgivning; det skyldes, at dens spørgsmål ikke mere sigter på dette samfunds grundlæggende modsætninger, for netop disse er ikke manipudlerbare. Afhængighedsforholdet til overfladefænomenerne, som kun systematiseres og pedantiseres, men også den grundlæggende indforståethed med det bestående samfund, udtrykker slutteligt dens affirmative, ja apologetiske karakter. En politisk økonomi for proletariatet må derimod netop spørge efter de grundlæggende modsigelser, undersøge deres bevægelse, spørge efter deres årsag og fremtrædelsesformer, for den vil netop gennem påvisningen af

64. Henryk Grosssmann, Das Akkumulations- und Zusammenbruchgesetz des kapitalistischen Systems (genoptryk), Frankfurt 1967, s. 202.

65. I årsberetningen, JG, 1966, Ziff. 233 hedder det: »Derimod ser vi også for 1967 ingen alvorlig fare for beskæftigelsen, skønt bekymringerne for, at befolkningen bevæger sig ind i struktursvage regioner, ikke er os fremmede. Hovedgrunden til denne tillidsfuldhed er tegnene på en kraftig økonomisk ekspansion i vigtige nabolande ... Få uger efter denne dom fra november 1966 havde vi over en million arbejdsløse (incl. gæstearbejdere, kvinder og deltidsarbejdere, som helt faldt ud af produktionsprocessen). 
dette samfunds bevægelseslove levere de videnskabelige forudsætninger for dets ændring.

For det andet: de konsekvenser, som den borgerlige videnskab og også Det økonomiske Råd uddrager i jagten på »rationel «, »videnskabeligt funderet« statslig politik, er imidlertid også politisk betydningsfulde: Vi ser en tendens til at sætte sig ud over institutionelle og konstitutionelle former, som staten i interessen for forøgelsen af sin interventionsevne pålægger stadig snævrere grænser - bortset fra at respektere kapitalforholdet. Retningen i sådanne forslag er entydigt bestemt: hen imod den autoritære stat, der med effektivt magtapparat udfra synspunktet om »systemtvangens rationalitet« bedre er i stand til virkeligt at gøre samfundet til et objekt for sin manupulation end den parlamentariske, forfatningsmæssige stat. Den autoritære stat er i sidste ende afløsningen af videnskaben som politisk rådgiver. For videnskabeligt indsigt i betydningen rationelt kalkulerede alternativer bliver efterhånden overflødigt, hvor den praktiske politik sætter sig ud over den kapitalistiske produktionsmådes lovmæssigheder og de samfundsmæssige modsigelser, og går over til direkte vold for at sikre kapitalens herredømme og den borgerlige klasse. Hvorfor findes der så videnskabelig politisk rådgivning i det borgerlige samfund, når dens bidrag til begrundelsen af den praktiske statsintervention rettere må anses for ringe, ringe ikke kun på grund af den generelle uoverensstemmelser, men på grund af den generelle grænse for statsinterventioner under kapitalismen? Vi kommer med dette spørgsmål til det andet aspekt, som eksemplet med Det økonomiske Råd tydeliggør. Videnskabelig rådgivning bør ikke kun betragtes instrumentalt i den hidtil diskuterede overfladiske betydning. Tværtimod fungerer videnskab og rådgivning også som ideologi, og det i en specifik betydning i forbindelse med det statslige bureaukratis dispositioner i videste omfang. De mystificerede bevidsthedsformer bestyrkes ikke kun gennem videnskaben og dens tilsyneladende neutrale karakter; men for statsbureaukratiet og dens politik har videnskaben derudover den funktion - ikke blot at begrunde handlingsprogrammer - men frem for alt også at tilvejebringe adfardsprogrammer. Den moderne socialdemokratisme ville overhovedet ikke være forståeligt uden den »videnskabelighed «, hvormed det "gamle klassekampsdogme« for det første er blevet benægtet, og hvormed der for det andet er blevet iværksat den teknokratiske »ideologifrie « forandring af den praktiske adfærd og af de politiske programmer. Videnskaben er i dens forhold til den borgerlige stats ikke eller kun lidt brugbar som begrundelse for praktisk politik, dette fremgår også af Det økonomiske Råd; ikke mindst derfor klager "praktikerne« til stadighed over videnskabens "praksis-fremmedhed « og over den videnskabelige uddannelse. Men i det borgerlige samfund er videnskaben uundværlig for dannelsen af $d o k$ triner, for opkomsten af et bestemt politisk-ideologisk klima, for den generelle 
begrundelse af stratergier, selv for stabiliseringen af klassespaltningen, hvor de videnskabeligt uddannede dog i reglen hører til den herskende klasse. For at udtrykke det mere præcist: Det økonomiske Råds vurdering, for at blive ved vores eksempel, har en større funktion for de parlamentariske partiers diskussioner end for regeringens planer med den økonomiske politik. Offentlighedens teknokratiske enstemmighed, eller det, som endnu eksisterer af den, lader sig direkte aflede af disse vurderingers funktion.

I denne formidlede betydning har den borgerlige videnskab således også en funktion for dette samfund, nemlig for at sikre herredømmet. Men det betyder også, at den må bekæmpes i denne formidlede betydning, og ikke som direkte instrument for den herskende klasse, ikke som undertrykkelsesinstrument for den, da den overhovedet ikke formår at være det. ${ }^{66}$ Det borgerlige samfund ville have en evig levetid, hvis dets funktionsdygtighed ville stige med den borgerlige videnskabs fremskridt. Selv de mest tilfilede og raffinerede teorier og modeller ophæver ikke betingelserne og grænserne for den statslige aktion i dette samfund, således som det er blevet beskrevet i denne artikels foregående afsnit.

66. Vi er hermed tilbage til den i begyndelsen (jvf. fodnote 5) omtalte debat. Det vidner blot om idealistisk bevidsthed, hildet i den borgerlige selvforståelse at ville bekæmpe den borgerlige videnskab, fordi den giver »modeller for den koloniale kontrarevolution« (Horlemann) osv., og dermed er et imperialistisk undertrykkelsesinstrument: For det første med en sådan opfattelse begribes den virkelige formidlingsproces af videnskab og politik ikke, sådan som vi her har forsøgt at karakterisere den, og for det andet ses den statslige politiks begrænsethed i kapitalismen ikke, en begrænset, som ingen nok så udviklet borgerlig videnskab kan ophæve; en anden antagelse vil vidne om idealistisk politisk forståelse - som i øvrigt også manifesterer sig i de intellektuelle hoveder ved partidannelser - til skade for klassekampen. 